Yeshiva University, Cardozo School of Law

LARC @ Cardozo Law

Articles

Faculty

1991

\title{
The Fall and Rise of the Criminal Contingent Fee
}

Peter Lushing

Benjamin N. Cardozo School of Law, plushing@comcast.net

Follow this and additional works at: https://larc.cardozo.yu.edu/faculty-articles

Part of the Law Commons

\section{Recommended Citation}

Peter Lushing, The Fall and Rise of the Criminal Contingent Fee, 82 Journal of Criminal Law and Criminology 498 (1991).

Available at: https://larc.cardozo.yu.edu/faculty-articles/368

This Article is brought to you for free and open access by the Faculty at LARC @ Cardozo Law. It has been accepted for inclusion in Articles by an authorized administrator of LARC @ Cardozo Law. For more information, please contact larc@yu.edu. 


\title{
THE FALL AND RISE OF THE CRIMINAL CONTINGENT FEE
}

\author{
PETER LUSHING*
}

Table of Contents

I. Introduction ............................ 500

II. The Traditional Rule: Criminal Contingent Fee Agreements Are Unenforceable ..................... 503

III. The Recent View: Criminal Contingent Fees Are Unethical ............................. 510

IV. Justifications For The Ban on Criminal Contingent Fees ................................... 513

A. How Criminal Lawyers Set Fees............. 514

B. Conflict of Interest Rationales for the Prohibition . 515

i. Conflict of Interest: A Definition .......... 515

ii. Conflicts Arising from Attorney's Incentive to Obtain Acquittal ..................... 517

iii. Criminal Contingency vs. Civil Contingency ... 521

iv. Contingent Fees vs. Retainers, Hourly Fees, and "Stairstep" ..................... 522

v. Regulating Contingency Conflicts ......... 523

vi. Critique of the Conflict Rationale .......... 524

C. Supposed Immorality of the Criminal Bar ....... 526

D. Miscellaneous Justifications $\ldots \ldots \ldots \ldots \ldots \ldots \ldots .529$

i. Lack of Res ....................... 530

ii. "Necessary Evil".................... 530

iii. Overreaching ...................... 531

iv. Misleading the Client .................. 534

v. Protection of the Bar ................. 535

V. The Niche For Contingent Fees ............... 536

VI. Congress and the Supreme Court Legalize Contingent Fees .................................. 538

A. Contingency Imposed by Possibility of Forfeiture.. 539

B. Ethics and the Constitutional Right to Counsel.... 542

* Professor of Law, Benjamin N. Cardozo School of Law. 
C. Formal vs. Practical Contingency............ 544

D. The Present and Future of Contingent Fees...... 545

VII. Conclusion ............................ 546 


\section{INTRODUCTION}

Contingent fees for criminal defense attorneys-agreements under which the attorney's fee depends upon the result obtained in the case-are almost uniformly considered unethical and illegal. ${ }^{1}$ Yet the American Bar Association ethics ban on criminal contingent fees $^{2}$ did not appear in its 1908 Canons of Ethics ${ }^{3}$ and in fact was not introduced until the Model Code in 1969.4 In 1989, the course reversed itself with the Supreme Court's implicit approval of criminal fees paid on a de facto contingency basis. ${ }^{5}$

This Article will explore the conventional arguments for the ban on criminal contingent fees. In this Introduction, however, I will suggest that the motives for the ethics prohibition derive from a submerged, unstated source, giving a curbside psycho-legal analysis designed not to prove but to provoke.

From Colonial times, statutes providing for counsel for indigent criminal defendants have existed, but the actual historical practices of the various states cannot be considered humanitarian. ${ }^{6}$ Aside from those instances when lawyers volunteered their services, poor criminal defendants often simply pled guilty without counsel as a formality before being carted off to prison. One variation, which must have looked like a reform at the time, was to assign a lawyer present in the courtroom to make an on-the-spot consultation before the plea. $^{7}$ More effective means of representation for indigent criminal defendants, beginning with voluntary defender and legal aid society assistance programs, and later followed by public defender programs, were established gradually. ${ }^{8}$

Until well into this century the overall situation for criminal defendants remained grim: In 1926, two-thirds of the cases in Philadelphia were tried without defense counsel, and as late as 1961, nearly half the country's poor defendants were similarly

1 See, e.g., People v. Winkler, 71 N.Y.2d 592, 596, 523 N.E.2d 485, 487, 528 N.Y.S.2d 360,362 (1988) ("[w]e strongly support the unanimous view" that criminal contingent fees should be prohibited.).

2 Model Rules of Professional Conduct Rule 1.5(d)(2) (1983) [hereinafter MOdel Rules].

3 Canons of Ethics Canon 13 (1908) ("Contingent fees, where sanctioned by law, should be under the supervision of the court, in order that clients may be protected from unjust changes.") [hereinafter CANONS].

4 Model Code of Professional Responsibility DR 2-106(C) (1980) [hereinafter MOdel Code].

5 See discussion infra Part VI.

6 William H. Beaney, The Right to Counsel in American Courts 137-38 (1955).

7 Ellery E. Cuff, Public Defender System: The Los Angeles Story, 45 Minn. L.Rev. 715, 719 (1961).

8 Id. at 718 \& $\mathrm{n} .9$. 
unrepresented. ${ }^{9}$

While the Supreme Court recognized that criminal defendants must be permitted to use counsel in their defense, ${ }^{10}$ the Court did not recognize a constitutional guarantee of legal representation for indigent defendants in federal court until 1938." ${ }^{11}$ Finally, in 1963, in the landmark case Gideon $v$. Wainwright, ${ }^{12}$ the Court expanded this constitutional right and required an appointed lawyer for the poor in state prosecutions as well. This decision was part of the criminal rights revolution of the Warren Court, a policy sweep of particular benefit to the poor. In an earlier ruling that the Constitution required indigent defendants to be furnished a free transcript for appeal, the Court's plurality gave the rallying cry: "There can be no equal justice where the kind of trial a man gets depends on the amount of money he has." 13

Conceptual equality of the legal positions of rich and poor criminal defendants is one thing; courtroom reality is another. The Supreme Court did not do away with the obvious disparity: the "amount" of justice one received. The vigorousness of the defense if not the chances of a favorable disposition still depended in large measure on the competence and preparation time available to one's attorney. Most participants in the criminal court process would agree that a criminal defendant would be far better off with an expensive private defense lawyer of sterling reputation than with an overworked staff member of the local public defender's office or Legal Aid Society. ${ }^{14}$ Normally, the latter kind of lawyer is simply assigned to the indigent defendant under Gideon's command because the courts are usually not too concerned with the defendant's wishes in this regard. ${ }^{15}$

As the Supreme Court has observed, "[T]here are few defendants charged with crime, few indeed, who fail to hire the best law-

\footnotetext{
9 Herman I. Pollock, Equal Justice in Practice, 45 Minn. L. Rev. 737, 739, 749 (1961).

10 See Patton v. United States, 281 U.S. 276, 308 (1930).

11 See Johnson v. Zerbst, 304 U.S. 458, 463 (1938).

12372 U.S. 335 (1963).

13 Griffin v. Illinois, 351 U.S. 12, 19 (1956) (plurality opinion).

14 See, e.g., Argersinger v. Hamlin, 407 U.S. 25, 57 n.21 (1972) (Powell, J., concurring) (suggesting that the pay and work conditions of most public defender's offices attract legal talent of less experience than the private bar); Robert HermanN, Eric Single \& John Boston, Counsel for the Poor: Criminal Defense in Urban America 2022 (1977) (suggesting that case loads and office structures of public defender's offices may promote less effective representation of indigent criminal defendants than private lawyers can provide.).

15 See Peter W. Tague, An Indigent's Right to the Attorney of His Choice, 27 Stan. L.Rev. 73, 73-75 (1974) (the court will defer to the wishes of an indigent defendant concerning choice of counsel only in limited circumstances).
} 
yers they can get to prepare and present their defenses," 16 and as the Court recently restated, "[T]he harsh reality [is] that the quality of a criminal defendant's representation frequently may turn on his ability to retain the best counsel money can buy." 17 Despite the Court's acknowledgement, this "two-track" 18 system of criminal justice for the rich and the poor is unlikely to change. So long as the practice of law is a private profession, it will reflect the welfareleavened capitalist norms of the larger society: "You get what you (or the government) can pay for."

Fair-minded people, whatever their general view on the lot of the poor in our society, cannot be comfortable with a criminal justice system in which the accused's money or lack thereof plays a crucial role in the quality of his or her defense. I suggest that the 1969 ABA prohibition on criminal contingent fees arose from an impulse to repress the "dirty little secret" that the chance of going to prison or the gas chamber is dependent in significant part on one's personal wealth, something that has always been true but which became unbearable with the Supreme Court's guarantee of counsel for the poor. Allowing criminal contingent fees in the 1960's revolutionary atmosphere would have emphasized the relationship of money to a top quality defense at a time when the relevance of poverty was supposedly being swept away. Contingency fees graphically tie the lawyer's role in obtaining freedom to money, and that linkage is not comfortably containable within the four corners of a self-imposed code of morality that in many places reads like a paean to the nobility of lawyers. To be sure, if this scenario is correct, the code makers' embarrassment over contingent fees for the accused arose from a sense of decency.

This Article will criticize the stated reasons for this ethical ban and the case law making criminal contingent fee agreements unenforceable. It will also consider the role contingency fees could play in modern criminal practice. I will argue that with the advent of a 1989 Supreme Court decision interpreting and upholding a statute that virtually legalized contingent fees in an important class of criminal cases, the ethical ban on criminal contingency fees should be repealed.

16 Gideon v. Wainwright, 372 U.S. 335, 344 (1963).

17 Caplin \& Drysdale, Chartered v. United States, 491 U.S. 617, 630 (1989) (quoting Morris v. Slappy, 461 U.S. 1, 23 (1983) (Brennan, J. concurring)).

18 Hermann et al., supra note 14, at 21. 


\section{The Traditional Rule: Criminal Contingent Fee AGREEMENTS ARE UNENFORCEABLE}

In order to discourage undesirable conduct, courts have long claimed the right to refuse to enforce contracts whose performance would be illegal or against "public policy." 19 At one time even civil contingent fee arrangments were illegal in most states, though they began to gain acceptance during the nineteenth century. ${ }^{20}$ Criminal contingency fees, in contrast, have continued to be viewed by courts as against public policy.

F.B. Mackinnon, one of the most influential authorities on criminal contingent fees, ${ }^{21}$ remarked on support for the public policy against allowing such fees:

The third area of practice [besides domestic relations and government lobbying] in which the use of the contingent fee is generally considered to be prohibited is the prosecution and defense of criminal cases. However, there are so few cases, and these are predominantly old, that it is doubtful that there can be said to be any current law on the subject. ${ }^{22}$

MacKinnon believed that, given such sparse case authority, one could rely on the "consensus among commentators" for the proposition that the criminal contingent fee is void as against public policy, but he did not cite any commentators. ${ }^{23}$ Instead, MacKinnon relied on citations to three cases. ${ }^{24}$

In Weber $v$. Shay, ${ }^{25}$ a lawyer sued on a contract to pay him for services regarding potential charges against a client. The lawyer had agreed to try to prevent an indictment by preparing testimony, and to prevent disgrace of the client "as much as our influence and power could." 26 The trial judge charged the jury that counsel could perfectly well investigate the prosecution's witnesses and re-

\footnotetext{
19 Restatement (Second) of Contracts ch.8, Introductory Note, at 2 (1981).

20 Lester Brickman, Contingent Fees Without Contingencies: Hamlet Without the Prince of Denmark?, 37 UCLA L. REv. 29, 36-37 (1989).

21 See, e.g., Standards Relating to the Prosecution Function and the Defense Function sec. 3.3(e) cmt. at 209 (Tentative Draft March 1970)(The Advisory Committee on the Prosecution and Defense Functions' ABA Project on Standards for Criminal Justice cites MacKinnon's work as authoritative.); ABA Comm. on Professional Ethics, Informal Op. 832 (1965) (MacKinnon "helpful," but not wholly dispositive); MODEL CODE, supra note 4, DR 2-106(C) n.90 (1980)(MacKinnon's work "guided" ABA policy); F.B. MacKinnon, American Bar foundation, Contingent fees for legal Services: A Study of Professional Economics and Responsibilities (1964).

22 See MacKinnon, supra note 21, at 52 (citations omitted).

23 Id. See also, id. at n.94 (citing only a proposed rule for the Supreme Judicial Court of Massachusetts).

24 See discussion infra at notes 25-42 and accompanying text.

2546 N.E. 377 (Ohio 1897).

26 Id. at 378.
} 
port to the prosecutor their bad character or motives. ${ }^{27}$ The Ohio Supreme Court reversed, holding that the contract was void as against public policy because it promoted counsel's improper use of influence on the grand jury to impede justice. ${ }^{28}$ The trial court's jury instructions, which would have barred recovery only upon proof of actual obstruction of justice, were considered too lenient. ${ }^{29}$ Instead, the Ohio high court presumed that the contract encouraged "secret and corrupt practices," and it considered proof of improper conduct immaterial because of the "corrupting tendency" of the agreement. ${ }^{30}$ Weber, then, lends little support to MacKinnon's general proposition because the case was decided on policy grounds not directly related to the propriety of criminal contingency fees themselves.

MacKinnon next cited Peyton v. Margiotti, ${ }^{31}$ a case in which the plaintiff's lawyer had agreed to attempt, on a contingent basis, to get a convicted murderer pardoned. The court held that the contract was against public policy, reasoning that contingent fee rules are stricter in criminal than in civil practice "because of the danger of corrupting justice."32 As authority, the court cited Hatzfield $v$. Gulden, ${ }^{33}$ which had held that all monetary contracts to obtain a pardon are void even if the money is for an attorney's fee, whether fixed or contingent ${ }^{34}$. The Hatzfield court, as did the court in Weber $v$. Shay, concluded that in certain matters the charging of any fees for services rendered by criminal law practitioners would be against public policy. ${ }^{35}$ Hatzfield was not decided upon the use of contingent fees per $\mathrm{se}^{36}$ and the case was cited by the Peyton court only for the broad proposition that bargains to secure pardons are illegal. ${ }^{37}$ Thus, Peyton's statements about contingent fees were superfluous. ${ }^{38}$

\footnotetext{
27 Id. at 379.

28 Id. at 380.

29 Id. at $378-80$.

30 Id. at 380.

31156 A.2d 865 (Pa. 1959).

32 Id. at 867.

337 Watts 152 (Pa. 1838), cited in Peyton, $156 \mathrm{~A} .2 \mathrm{~d}$ at 867.

34 Hatzfield, 7 Watts at 155.

$35 \mathrm{Id}$. at 154.

36 Id. at 153 ("remuneration for his services and loss of time"). While the lawyer had made a separate agreement with the trustees of the prisoner's property which paid him part of his fee on a contingency basis, that agreement was not at issue in the case. $I d$. at 153-55.

37 Peyton, 156 A.2d at 867.

38 The Peyton court cited other cases relating to lawyer's fees and ethics, but these cases fail to add support to the proposition that the court opposed the use of contingent fees themselves in criminal cases. See id. (quoting Clippinger v. Hepbaugh, 5 Watts \& Serg. 315, 321 ( $\mathrm{Pa}$. 1843)) (prohibiting contracts "to procure or endeavor to procure the
} 
Two of the seven justices in Peyton concurred on other grounds. They stated that the contingent fee is "a necessity for a poor man. ... In many civil and criminal cases a poor person is unable to engage [his choice of] lawyer except on the basis of a contingent fee. Provided such a fee is fair and reasonable," the concurring justices stated, the contract should be upheld. ${ }^{39}$

The third case cited by MacKinnon, Baca $v$. Padilla, ${ }^{40}$ concerned an agreement to assist a prosecutor; the arrangement provided for a reasonable fee in the event of the accused's acquittal, but it provided a larger fee in the event of a conviction. The court reasoned that since the state is presumed to have the resources to prosecute a case, there is no need to attract private attorneys by means of contingent fees to assist in prosecution. ${ }^{41}$ Furthermore, an assistant working on a contingent fee would have an interest in the outcome of the case and might seek a conviction regardless of innocence, and prosecutors should not be interested in outcomes, only in justice. ${ }^{42}$

Baca stands only for the proposition that a contingency fee is improper for prosecutors. MacKinnon overlooked this distinction. Prosecutors and defense counsel have widely differing duties. As the ABA Standards for Criminal Justice state, "The duty of a prosecutor is to seek justice, not merely to convict. ... The basic duty the lawyer for the accused owes to the administration of justice is to serve as the accused's counselor and advocate . ..."43 Moreover, a contingent fee could color the exercise of a prosecutor's discretion, but a defense counsel has no comparable discretionary power.

MacKinnon's discussion of the meager case law trailed off in a tone of "it doesn't matter anyway," noting that contingent fees as a practical matter are unlikely in criminal cases and that the trend was

passage of an Act by the Legislature"); Peyton, 156 A.2d at 867 (quoting Bowman v. Coffroth, $50 \mathrm{~Pa}$. (9 Smith) 19, 23 (1868)) (prohibiting contracts to procure official appointments or "right[s] of administration").

39 Peyton, 156 A.2d at 870 (Bell, J., concurring) (reasoning that by requiring disclosure of an attorney's fee, the Pardon Board could prevent fees which it believed might promote a lawyer's improper use of influence with the Board).

40190 P. 730 (N.M. 1920).

41 Id. at 732. Accord, Price v. Caperton, 62 Ky. (1 Duv.) 207, 208 (1864) (prohibiting contingency fees for assisting in prosecution, and finding little need for any compensation as providing assistance to the government would be an attorney's "privilege" and "civic duty"). But cf. People ex rel. Clancy v. Superior Court, 705 P.2d 347, 351-52 (Cal. 1985) (reasoning that the use of a contingent fee is improper in such a case on the grounds that it taints the government's neutral pursuit of justice; approving, however, of the state's use of private counsel under appropriate fee arrangements), cert. denied sub nom., City of Corona v. Superior Court, 475 U.S. 1121 (1986).

42 Baca, 190 P. at 731-32.

43 I Standards for Criminal Justice 3-1.1(c), $3.7 \mathrm{cmt}$., 4-1.1(b) (2d ed. 1980)(hereinafter ABA Standards); see also, Model Rules, supra note 2, at Rule 3.8. 
toward public funding of criminal defense fees. ${ }^{44}$

Other cases that discuss the enforceability of criminal contingent fee arrangements reflect the distrust of criminal attorneys evident in Weber and Peyton. In Ormerod v. Dearman ${ }^{45}$ the client agreed that if the attorney got a fornication prosecution settled and withdrawn by the husband he would be paid $\$ 2,000.46$ Via the lawyer, the defendant settled with the husband, and the prosecutor apparently withdrew the action. ${ }^{47}$

The Ormerod court said the contract with the attorney was to prevent a case from coming to court, and that one cannot contract to stifle a prosecution for a fee, even for a misdeameanor in the control of the parties. ${ }^{48}$ Allowing such an arrangement, the court noted, would lower the standards and impair the "dignity and usefulness" of the legal profession. ${ }^{49}$ To the court, the contract implied an understanding to use unprofessional means in resolving the lawsuit.50 Although the court disapproved of the contract, its decision did not turn on the contingent nature of the fee, but on the substance of the contract: The principle was that "contracts which have for their subject-matter any interference with the creation of laws or their due enforcement are against public policy and therefore void." 51 The Ormerod court analogized the matter to offers to obtain a pardon for money:52 "[W]e do not wish to see advertisements that pardons will be obtained at the lowest price, nor anything which approaches to it ...."53 The court concluded with a flourish typical of the time: "The law guards with jealousy every avenue to its courts of justice, and strikes down everything in the shape of a contract which may afford a temptation to interfere with its due administration." 54

In these days of overcrowded criminal courts Ormerod's premise is unappealing. An assault complainant's wish that the charge be withdrawn is a valid reason for the prosecutor not to prosecute, ${ }^{55}$ and in Ormerod the complainant voluntarily agreed not to pursue the

44 See Mackinnon, supra note 21, at 52-53.

$45100 \mathrm{~Pa}$. (4 Outerbridge) 561 (1882).

46 Id. at 563.

47 Id.

48 Id.

49 Id.

50 Id.

51 Id. at 564.

52 Id. at 563-64.

53 Id. at 564 (quoting Hatzfield v. Gulden, 7 Watts 152, 155 (Pa. 1838)). See also, supra notes 33-37 and accompanying text.

54 Ormerod, $100 \mathrm{~Pa}$. (4 Outerbridge) at 564.

55 Wayne R. LaFave \& Jerold H. Israel, Criminal Procedure § 13.2(a) (1984). 
action further. ${ }^{56}$ Viewing private attempts to settle relatively minor criminal disputes as improper seems very odd in our present world of clogged dockets. ${ }^{57}$

By the second half of this century, citation to codified, widely accepted authority was sufficient to hold criminal contingency fee agreements "void as against public policy." 58 In fact, it was considered defamatory even to accuse an attorney of having entered into such an arrangement. ${ }^{59}$

While most courts viewed criminal contingent fees with extreme disfavor, the Supreme Judicial Court of Massachusetts actually upheld a complaint brought to enforce a criminal contingent fee agreement. In $O^{\prime}$ Donnell $v$. Bane,$^{60}$ the court reviewed an attorney's complaint against his former client for failure to perform his part of a contingent fee agreement after the client's acquittal on criminal charges. ${ }^{61}$ At trial, the defendant had moved for a directed verdict on the basis that the criminal contingent fee arrangement violated a court rule, and he requested jury instructions to that effect. ${ }^{62}$ The Massachusetts high court, however, ruled that the defendant's answer to the complaint failed to preserve the defense of "unenforceability or illegality" as against public policy because this issue had not been properly pleaded. ${ }^{63}$ The court stated that it would overlook a defendant's failure to plead this defense "only where the evidence shows a contract which is inherently wrongful or which is violative of some fundamental principle of public policy."64 Despite plaintiff's testimony which indicated a possible contingent fee ar-

56 Ormerod, $100 \mathrm{~Pa}$. (4 Outerbridge) at 563.

57 In fact, considerable effort has recently been spent in extending alternative means of dispute resolution movement, so that they may encompass many instances where the criminal charge is a lesser offense. See, e.g. STEPhen B. GoldBerg ET. AL., Dispute ResoLUTION 12 (1985).

58 Genins v. Geiger, 240 S.E.2d 745, 747 (Ga. Ct. App. 1977) (citing Restatement (First) of Contracts sec. 542(2) (1932)); see also, Model Code, supra note 4, DR 2106(c). The plaintiff in Genins attempted to pursue these claims again, but the original holding against the use of contingency fees in certain matters was upheld. See, Genins v. Geiger, 254 S.E.2d 913, 913-14 (Ga. Ct. App. 1978), cert. denied, 444 U.S. 991 (1979).

$59 \mathrm{See}$ McCall v. Courier-Journal \& Louisville Times Co., 623 S.W.2d 882, 885 (Ky. 1981), cert. denied, 456 U.S. 975 (1982) (holding that allegations in news reports that an attorney required a criminal defendant to pay a contingency fee, along with reports of the attorney's plan to "fix" a case, were defamatory as a matter of law if published when known to be false). See also, Steere v. Cupp, 602 P.2d 1267, 1271 (Kan. 1979). In Steere, the court ultimately ruled against the plaintiff, however, because it found the reported use of contingency fees by the lawyer "substantially true." Id. at 1274 .

60431 N.E.2d 190 (Mass. 1982).

61 Id. at 191.

62 Id.

63 Id. at 192.

64 Id. (quoting Gleason v. Mann, 45 N.E.2d 280, 282 (Mass. 1942)). 
rangement, and despite the court's recognition of public policy against criminal contingent fees, the court found that while the evidence was sufficient to "warrant" a finding of a contingent fee agreement, the evidence did not "compel" such a finding. ${ }^{65} \mathrm{By}$ allowing procedural rules to prevent it from striking down an apparent criminal contingency fee agreement, the O'Donnell court casts doubt on the strength of public policy against such practices.

Prior to 1981 , the case law ${ }^{66}$ developed against the prestigious backdrop of the Restatement (First) of Contracts (1932), which explicitly stated that an agreement to conduct a criminal case for a contingent fee was illegal.67 Pulling no punches, the Restatement lumped criminal contingent fees in its subdivision on "Bargains Tending To Obstruct the Administration of Justice" 68 along with such disreputable strategies as bargains to suppress evidence ${ }^{69}$ and agreements to enforce unfounded claims. ${ }^{70}$ When the American Law Institute adopted this prohibition there was no discussion on the floor. ${ }^{71}$

Subsequent authorities have similarly ignored or dismissed criminal contingency fees without thorough examination. The Restatement (Second) of Contracts does not deal with contingent fees and their ilk because "the subjects are so largely governed by legislation."72 Corbin, for his part, agreed without analysis that criminal contingent fees were illegal, but he cited only divorce cases. ${ }^{73}$ Williston similarly discussed only divorce cases, and did not mention a rule for criminal defense cases. ${ }^{74}$

An ALI Restatement of the Law Governing Lawyers which is now in progress will likely continue, as a matter of black-letter law, the ban on criminal contingent fees. ${ }^{75}$ The original commentary

65 Id. at 191, 193-94.

66 See Genins v. Geiger, 240 S.E.2d 745, 748 (Ga. Ct. App. 1977); Peyton v. Margiotta, 156 A.2d 865, 867 (Pa. 1959).

67 Restatement (First) of Contracts sec. 542(2) (student ed. 1933).

68 Id.

69 Id. at $\$ 554$.

70 Id. at $\$ 555$.

71 See William E. Mikell, Discussion of the Administration of the Criminal Law, 10 A.L.I. Proc. 101, 165 (Tentative Draft No. 2 1932). But cf., id. at 167 (discussing briefly the lack of state criminal statutes against champerty).

72 Restatement (Second) of Contracts, ch.8, Reporter's Note to Introductory Note at 4 (1981).

73 6A Arthur L. Corbin, Corbin on Contracts $§ 1424$ (1st ed. 1962).

74 Samuel Williston, A Treatise on the Law of Contracts § $1285 \mathrm{~A}$ at pp.933-34 (Walter H.E. Jaeger, ed., 3d ed. 1967). See also, id. at § 1716 (4th ed. 1972) (discussing the prohibition for contingent fees in criminal prosecutions.).

75 See Restatement (Third) of the Law Governing Lawyers sec. 47 and cmts. (Tentative Draft No.4, April 10, 1991) [hereinafter LAw Governing LaWYers]. 
recognizes, however, that the reasons for the traditional ban are "on balance unpersuasive."76 It finds the best rationale for the ban to be the lack of necessity for a contingent fee arrangement, because winning a criminal case does not increase the client's assets. ${ }^{77}$ The commentary notes the immorality-of-the bar argument, and contingent fee discouragement of plea bargaining. ${ }^{78}$ It points out problems in drafting a criminal contingent fee agreement, such as defining the outcome determining the size of the fee, ensuring that the fee will be paid, and explaining the complexities of the agreement to the client. ${ }^{79}$ The commentary adds that many lawyers might be unwilling to risk contingent non-payment and continue to demand advance payment. Why this would be a reason for prohibiting lawyers from making this risk assessment themselves is not stated.

After noting that, on the contrary, contingent fees might well promote effective assistance of counsel, the ALI commentary states "[i]t is desirable, on balance, that the law be changed so that clients who would find a contingent-fee arrangement agreement preferable to a flat fee would be permitted to exercise that preference." 80 This conclusion casts the contrary black-letter rule of the proposed as truly a "restatement," and not a forward-looking proposal. ${ }^{81}$

In a wave of distrust and misunderstanding, courts and commentators have summarily swept criminal contingent fees away without argument. The opinions do not seem informed by advocacy in favor of contingent fees and present no thorough analysis of the purported flaws of such fees other then gloomy forebodings about imagined sinister influences. The early opinions exhibit a general distrust of the criminal defense function and a distaste of what criminal defense lawyers do. F.B. MacKinnon's report on contingent fees-apparently the only one published at the time-characterized the criminal cases as old and few in number, yet his uncritical synthesis of the sparse caselaw gave it the status of iron authority. Within this uncritical context, the American Bar Association was getting ready to put its own imprimatur on the criminal contingent fee ban.

76 Id. This commentary was rejected by the ALI membership at the 1991 Annual Meeting, according to the author's conversation with a Reporter for the Restatement.

77 Id. at comment c(i). See also discussion infra part IV.D.i.

78 Id., $\$ 47$ and cmts.; see discussion infra part IV.B.ii, IV.C.

79 Id., $\$ 47$ and cmts.; but see discussion infra part V. (discussing proposed model contingency fee agreements).

80 Id., $\$ 47$ and cmts.

81 But see supra note 76. 


\section{The Recent View: Criminal Contingent Fees ARE UNETHICAL}

A few years before the ABA promulgated its first ethics code, ${ }^{82}$ a judge cautiously approved criminal contingent fees:

In criminal cases the objections to conditional fees are much more serious than in cases involving only questions relating to property; so serious indeed that it is probably best never to make any such contract with persons charged with crime. If made, the contract should relate and be expressly confined to services rendered on or in connection with the trial. ${ }^{83}$

This hedged approval of criminal contingent fees was replicated by early ABA statements of policy. ${ }^{84}$ When the ABA adopted the Canons of Ethics in 1908, the delegates devoted much more debate to proposed Canon 13 permitting contingent fees than to any other provision. ${ }^{85}$ Yet nothing was said on the floor about criminal contingent fees. ${ }^{86}$ Canon 13 deemed contingent fees ethical "where sanctioned by law", requiring that they should be reasonable and subject to the supervision of the court to avoid unjust charges. ${ }^{87} \mathrm{By}$ failing to use the terms "civil" or "criminal" this Canon literally made criminal contingent fees not unethical per se, and so ethics opinions upheld such arrangements. ${ }^{88}$ One ABA opinion stated in

82 The ABA's original CANONS of Ethics, adopted in 1908, relied extensively on a compilation of various ethics codes already adopted by many states, as well as on the works of George Sharswood and David Hoffman. Henry S. Drinker, Legal Ethics 2324 (1953). Neither the nation's first code of ethics, Alabama Code of 1887, nor the works of Sharswood and Hoffman, made specific reference to criminal contingency fees. See Code of Ethics Alabama State Bar Association Rule 51 (1887)(amended 1899) reprinted in Henry S. Drinker, Legal Ethics, supra at 362; George Sharswood, A Compend of Lectures on the Aims and Duties of the Profession of the Law, Delivered Before the Law Class of the University of Pennsylvania (1854), reprinted in George Sharswood, An Essay on Professional Ethics 158-69 (3d ed. 1869); David Hoffman, A Course of Legal Study Division IX, Resolution XXIV (2d ed. 1836).

83 Henry W. Williams, Legal Ethics and Suggestions for Young Counsel 70 (1906).

84 See Canons, supra note 3, at Canon 13 ("Contingent fees, where sanctioned by law. ...").

85 See 33 Reports of American Bar Association 55-86 (1908); see also, Drinker, supra note 82 , at $24 \& \mathrm{n} .17$ (describing how Canon 13 was the only one of thirty-two canons proposed but not adopted in its original form. It was later amended and passed after considerable debate.).

86 See 33 Reports of American Bar Association 61-85 (1908).

87 See supra note 84 and accompanying text. The 1933 amendment to Canon 13 reemphasized the role of judicial supervision over contingency fee arrangements, but such nominal supervision did little to restrict the growing use of contingency contracts by lawyers. See, 58 Reports of American Bar Association 152, 157-61 (1933).

88 See, e.g., North Carolina State Bar, Formal Op. 68 (1951) reported in Olavi Maru, Digest of Bar Association Ethics Opinions Op. 3092 (1970); North Carolina State Bar Formal Op. 359 (1961) reported in MARU, supra, at Op. 3383; Philadelphia Bar Associ- 
full: "Canon 13 applies to criminal cases. Irrespective of agreements, the lawyer should always be willing to have the court pass on the reasonableness of his charges under the various contingencies specified and should make such charges so reasonable that, if submitted to the court, it would sustain him." 89 A subsequent opinion reinforced the premise that criminal contingent fees were not always unethical by noting that the matter depended in part on legality..$^{90}$ If the ethics of the matter depended upon whether the fee was legal in the local jurisdiction, then clearly criminal contingent fees were not deemed unethical per se.

When the ABA adopted its superseding Model Code of Professional Responsibility in 1969, however, criminal contingent fees were explicitly made unethical per se. ${ }^{91}$ The Code provided that "[a] lawyer shall not enter into an arrangement for, charge, or collect a contingent fee for representing a defendant in a criminal case." 92 The Model Code did, however, allow for some civil contingency arrangements, which it justified on the basis that the relief awarded in civil cases produced a "res out of which the fee can be paid."93 "Public policy properly condemns contingent fee arrangements in criminal cases, largely on the ground that legal services in criminal cases do not produce a res with which to pay the fee." 94 The Code cited and quoted Peyton v. Margiotti ${ }^{95}$ and the MacKinnon

ation Comm. on Professional Guidance, Formal Op. 58-2 (1958) reported in MARU, supra, at Op. 4016 (1970); Virginia State Bar Standing Comm. on Legal Ethics, Formal Op. 88 (1959) reported in MARU, supra, at Op. 4457; Chicago Bar Assoc. Comm. on Professional Responsibility, Formal Op. 84-9 (1985) reported in 1 NATIONAL RePORTER ON LEGAL ETHICS AND Responsibility IL:Opinions:25-26 (1985). Contra, Arizona State Bar Assoc., Formal Op. 168 (1965) reported in MARU, supra at Op. 5913 (1972 Supp.).

89 ABA Comm. on Ethics and Professional Responsibility, Informal Op. 337 (1967), reported in Olavi Maru, 1970 Supplement to the Digest of Bar Association Ethics OPINIONS Op. 5045 (1972).

90 ABA Committee on Ethics and Professional Responsibility, Informal Decision 832 (1965).

91 See Model Code, supra note 4, DR 2-106(C) (1980). The proposed code had been thoroughly studied by state and local bar associations, so it is not surprising that the very limited floor debate in the ABA House of Delegates did not mention contingent fees. See 94 ABA REP. 382-92 (1969). The other ABA prohibition of contingency fees, in domestic relations cases, did not appear in the MODEL CODE and was not adopted until its inclusion in the Model Rules. See Model Rules, supra note 2, Rule 1.5(d)(1).

92 MODel Code, supra note 4, DR 2-106(C) (citation omitted).

93 Id. at EC 2-20.

94 Id. The prohibition on contingency fees did not exclude consideration of the case's outcome at all in civil cases: A New York State Bar Association opinion held that while criminal contingent fees are prohibited, civil contingent fees may be based partly on the results of the case-within the restrictions of the Model Code, supra note 4, DR 2-106(B)(4). New York State Bar Assoc. Comm. on Professional Ethics, Formal Op. 412 (1975), reported in MARU, supra note 88, at Op. 9172 (1977).

95 See supra note 31 and accompanying text. 
monograph. ${ }^{96}$

While most states adopted the ABA's prohibition, ${ }^{97}$ they enforced it with a mere "slap on the wrist" if the only alleged infraction was charging a criminal contingent fee. ${ }^{98}$

In 1983 the ABA superseded the Model Code with its Model Rules of Professional Conduct. The proposed draft by its Commission on Evaluation of Professional Standards did not include a prohibition of criminal contingent fees, but allowed the matter to turn on the law of each state. ${ }^{99}$ The ABA House of Delegates, however, adopted an explicit ban on criminal contingent fees ${ }^{100}$ without debate, via an amendment drafted by the International Association of Insurance Counsel (a state bar association had also proposed a ban). ${ }^{101}$ The Model Rules have been adopted by a majority of states. ${ }^{102}$

The ABA also speaks to criminal defense ethics through its influential Standards for Criminal Justice, ${ }^{103}$ which is intended to provide both guidance and authority to the bench as well as the bar. ${ }^{104}$ Standard 4-3.3 states that it is unprofessional to have a contingent fee arrangement. The commentary notes that such fees have long been forbidden and repeats the rationales of the ethics codes while hearkening back to another era in language reminiscent of the old

96 See MacKinnon, supra note 21 et. seq. and accompanying text.

$97 \mathrm{See}$ M.L. Proctor \& Robin Alexander-Smith, Code of Professional ResponsiBILITY BY STATES vi (1980) (table showing that only fourteen states adopted rules on contingency fees which differed from the ABA MODEL CODE DR 2-106.).

98 See, e.g., In re Steeve, 536 P.2d 54 (Kan. 1975) (public censure to be published in the official state reporter); In re Fasig, 444 N.E.2d 849 (Ind. 1983) (public reprimand and court costs); In Matter of Stivers, 516 N.E.2d 1066 (Ind. 1987) (reprimand and court costs); but cf. State v. Hilton, 538 P.2d 977, 983 (Kan. 1975) (censure despite lack of evidence of a contingency agreement; the court held that a demand for an additional fee during a critical stage of criminal proceedings violated the spirit of the MoDEL CoDE's prohibition on criminal contingent fees). See also, Office of Disciplinary Counsel v. Zauderer, 461 N.E.2d 883, 887 (Ohio 1984), aff'd in part and reversed in part on other grounds, 471 U.S. 626, 654-5 (1985).

99 Model Rules, supra note 2, Rule 1.5(c) notes on Legal Background at 36 (Proposed Final Draft 1981).

100 Model Rules, supra note 2, Rule 1.5(d)(2).

$101 \mathrm{See} 107$ ABA REPORTS 622 (1982).

102 See ABA/BNA Lawyers' Manual on Professional Conduct 01:3-01:4 (American Bar Association and Bureau of National Affairs 1990) [hereinafter ABA/BNA MANUAL]. 103 The standards have been cited by courts thousands of times. See, Shepard's Criminal Justice Crtations (October 1991) (reporting over 60 pages of citations to the standards). But see, North Carolina State Bar Formal Op. 728 (1970) (explicitly rejecting the ABA StANDARDS and permitting criminal contingent fees), reported in MARU, supra note 88, at Op. 9478 (1975 Supplement). The North Carolina Bar later reversed itself. See, North Carolina State Bar, Formal Op. 843 (1973), reported in MARU, supra note 88, at Op. 9594.

104 ABA Standards, supra note 43 , at xix-xx. 
cases, stating that a contingent arrangement may "tempt the advocate to employ improper or corrupt tactics to enhance the fee."105 While civil contingent fees are necessary lest a large part of the public be denied the opportunity to litigate, "[i]n the administration of criminal justice the stakes are high, and thus the danger of abuse resulting from a contingent fee is especially great." 106 The commentary concludes that there is no problem of lack of legal representation because of the constitutional right to counsel.

In contrast to the ABA, the American Trial Lawyers' Association permits criminal contingent fees in its code of ethics. ${ }^{107}$ The Association argues that there is even more reason to allow a contingent fee in criminal cases than in civil cases, because the criminal loser goes to prison and is thus less able to pay than if he had been acquitted. Moreover, the Trial Lawyers' Association asserts, a lawyer will work on a contingency only if the defense seems strong. ${ }^{108}$ Unscrupulous lawyers would be no more likely to fabricate a defense on a contingency than if they were on a straight retainer fee agreement. ${ }^{109}$ In sharp contrast to the ABA models, the Trial Lawyer's Association code has not been adopted by any jurisdiction. ${ }^{110}$

The ABA did not focus on criminal contingent fees when it adopted the permissive 1909 Canon, probably because of the relative unimportance of the issue. By the time it adopted the Model Code in the late 1960's, MacKinnon's monograph had been enshrined as the authoritative study of contingent fees, and the ABA uncritically adopted his conclusions in partial justification for its ethics ban. The Model Rules of the early 1980's have likewise perpetuated the ban on criminal contingency fees without any subsequent critical analysis.

\section{Justifications for the Ban on Criminal Contingent Fees}

Freedom to contract is still somewhat of a presumption in the

105 Id. at 4.37, supra note 43, at $4.37 \mathrm{n} .10$ (citing MAcKinnon, supra note 21 , at 52 ). See Model Code, supra note 4, DR 2-106(C); ABA STANDARds, supra note 43, at 4.11S (1986 Supp.) (citing Model Rules, supra note 2, Rule 1.5(d)).

106 ABA STANDARDS, supra note 43, at 4-3.3.

107 The American Trial LaWyer's Code of Conduct Rule 5.6(d) (1982) [hereinafter Trial LaWyer's Code of Conduct].

108 Id.

109 Id. at $\mathrm{cmt}$.

110 See John W. Hall, Contingent Fees in Criminal Cases: Has the Supreme Court Sanctioned Them?, The Champion (NACDL) 20 (Dec. 1990). The National Association of Criminal Defense Lawyers (NACDL) considered deeming contingent fees ethical in the wake of Supreme Court decisions (discussed in the last part of this Article), but gave up the effort in August 1990 when its Ethics Advisory Committee sharply divided on the issue. Id. 
law, and a contingent fee agreement is a contract. ${ }^{111} \mathrm{~A}$ fair starting point for evaluation of a prohibition of contract is to put the burden of proof on those who would infringe upon contractual freedom and thus interfere with individual liberty and market mechanisms.

\section{A. HOW CRIMINAL LAWYERS SET FEES}

Evaluation of ethics rules requires examination of existing practices. Fee-setting by criminal lawyers must be viewed through the distorting prism of the criminal lawyer's fundamental remuneration problem: getting paid. Criminal lawyers are more concerned than other lawyers with collection of the fee-after all, their clients are mostly criminals. ${ }^{112}$ However easily a criminal lawyer might eventually reduce a client's obligation to a judgment, an agreed-upon fee that is not collected is no fee at all.

As a practical matter, the lawyer's fee in a criminal case is generally a flat fee paid in advance. A leading statement on the subject advises setting a single fixed fee if possible, avoiding hourly or "stairstep" rates. 113 Criminal clients are not inclined to pay after a losing trial, and an acquittal, known to them as "justice," is not something for which they often feel obligated to pay. ${ }^{114}$ Total feegrabbing at the earliest moment is further raised to a feverish pitch by the reluctance of many courts to let defense attorneys withdraw simply because they have not been paid.115 Attorneys are advised, then, to collect "while the tears are flowing." 116

One noted practitioner has stated that most serious cases are, as a practical matter, on a contingency fee because few lawyers get their full fee up front, some installments are not due until after trial, and if the client is imprisoned, he is unlikely to pay. ${ }^{117}$ Even on the dubious assumption that were the client not imprisoned he would pay the balance, this practitioner is probably over-generalizing. Criminal lawyers who work with white collar clients and other defendants from the higher economic and social strata have several ways of looking forward to getting most or all of their fee by the

\footnotetext{
111 John D. Calamari \& Joseph M. Perillo, Contracts $\$$ 1-3 (3d ed. 1987).

112 american Bar Association, How to Set and Collect Attorney Fees in CrimiNAL CASEs passim (1985) [hereinafter How to SET FeEs].

113 Lionel R. Barrett, The Ten Commandments of Setting and Collecting Attorneys Fees in Criminal Cases, The Champion (NACDL) 3 (Aug. 1983).

114 John W. Hall, Professional Responsibility of the Criminal Lawyer 149 (1987).

115 How to SET FeEs, supra note 112, at 9, 25.

116 HALL, supra note 114, at 159.

117 Patrick M. Wall, Lawyers' Fees and Professional Ethics, 2 Litigation 3, 4 (Summer 1976).
} 
time of verdict. These methods include working on a full retainer, or on partial retainer plus either an hourly fee (if and when the retainer is exhausted) or on a series of sub-retainers ("stairsteps") as the prosecution survives various hurdles, such as grand jury presentation, motion to suppress evidence, and plea-bargaining. ${ }^{118}$

Clientele from the lower economic strata are asked to protect their lawyers with a retainer paid up-front to cover the entire prosecution. ${ }^{119}$ Necessity is the mother of ingenuity for the criminal practitioner, who might first silently determine his fee, then quote the client a fee twice as large, and request that he get paid "one-half" up-front. ${ }^{120}$ Notwithstanding Professor Brickman's recent forceful argument that nonrefundable retainers are illegal and unethical as in conflict with the client's right to discharge his lawyer, ${ }^{121}$ nonrefundable retainers are used much of the time and can be substantial. ${ }^{122}$ In fact, a minimum fee agreement is recommended in an ABA publication, which sees hourly rates as unfair to "experienced lawyers [who] often resolve cases quickly and satisfactorily with only a modest investment of time."123

\section{B. CONFLICT OF INTEREST RATIONALES FOR THE PROHIBITION}

The strongest reason given for the ban on criminal contingent fees, albeit one not offered by the ABA, ${ }^{124}$ is that they lead to conflicts of interest between attorney and client. It is helpful in evaluating this rationale to first focus on what exactly a conflict of interest is, and how this definition relates to criminal representation.

\section{i. Conflict of Interest: A Definition}

Under the ABA's Model Rules, lawyers may not represent clients if representation may be "materially" limited by the lawyer's own interests, unless the lawyer reasonably believes the representation will not in fact be adversely affected, and the client consents after being fully informed of the circumstances and his or her op-

\footnotetext{
118 How to SET FeEs, supra note 112, passim.

119 Id. at 4; see also, Barry Tarlow, Fee Forfeiture: Apocalypse Now or Business as Usual?, 26 Trial 45, 46 (April 1990).

120 How to Set Fees, supra note 112, at 21.

121 Lester Brickman \& Lawrence A. Cunningham, Nonrefundable Retainers: Impermissible under Fiduciary, Statutory and Contract Law, 57 Fordham. L.Rev. 149 (1988).

122 Tarlow, supra note 119 , at 46.

123 How to SET FeEs, supra note 112, at 8.

124 See, Model Code, supra note 4, EC 2-20; id. at DR 2-106; Model Rules, supra note 2 , Rule 1.5 , cmt. The ABA STANDARDs refer to the principle that the lawyer should not have a pecuniary interest in the litigation in the context of corruption, not conflict of interest. ABA STANDARDS, supra note 43, 4-3.3 cmt.
} 
tions. ${ }^{125}$ The ABA says the "critical questions" include the likelihood that a conflict of interest will occur. ${ }^{126}$

An American Law Institute Restatement, currently being developed, states that there is no conflict of interest unless there is a "substantial risk" of material, adverse effect upon the representation, meaning a significant and plausible, even if not probable, risk. ${ }^{127}$ The ALI standard is to be applied objectively, from the perspective of an informed outside observer who is not dependent on testimony about the subjective opinion of the lawyer involved. ${ }^{128}$

Absent consent by the client, the lawyer cannot take on a client if there is a substantial risk that the lawyer's financial interests will materially and adversely affect representation. ${ }^{129}$ Informed consent by a client removes the conflict ${ }^{130}$ unless, inter alia, "[s]pecial circumstances render it unlikely that the lawyer will be able to provide adequate representation ...."131

While the ABA treats the probability of conflict as a factor relevant to whether the lawyer's representation is precluded, the Restatement, as just stated, defines "substantial risk" of adverse affect as an element in itself of conflict of interest; ${ }^{132}$ this may be a formal difference only. Both treatments allow conflict-ridden representation to continue under some circumstances if the client knowledgeably consents. ${ }^{133}$ Although a conflict from the fee could therefore be disregarded because of the client's consent, it hardly seems fruitful to imagine whether a client could be knowledgable enough to give informed consent to a contingent or any other fee. Besides, even informed consent does not remove the conflict in ALI "special circumstances," so a claimed informed consent would only push the issue forward to whether criminal contingent fees are "special circumstances render[ing] it unlikely that the lawyer will be able to provide adequate representation. ..."134

Both the ABA Rules and the current ALI draft fail to ask the one really important question: How much more likely is a contin-

125 MODEl Rules, supra note 2, Rule 1.7(b).

126 Id. at Rule $1.7 \mathrm{cmt}$.

127 Restatement (Third) of the Law Governing Lawyers sec. 201, cmt. c(iii) (Tent. Draft No. 4, April 10, 1991). See also, id. at $\$ 210$.

$128 I d$. at $\S 201, \mathrm{cmt}$. c(iv). The RESTATEMENT would reject the appearance of impropriety standard on the ground that that standard prohibits representations that might appear improper to an uninformed observer but which actually are not. Id.

129 Id. at § 206; see also, id. at § 210 .

130 Id. at $\$ 202(1)$.

131 Id. at $\$ 202(2)$ (c).

132 Id. at $\$ 206$.

133 Id. at $\$ 202(1)$.

$134 I d$. at $\$ 202(2)(c)$. 
gent fee to be detrimental to a client's representation than other fee arrangements? All fee arrangements create an attorney-client conflict. ${ }^{135}$ Why single out criminal contingent fees for prohibition?

\section{ii. Conflicts Arising from Attorney's Incentive to Obtain Acquittal}

The danger of conflict of interest from a criminal contingent fee arises from the incentive for the attorney to obtain an acquittal to collect his fee. This incentive arguably conflicts with the client's interest in obtaining a plea bargain, or, if the case goes to trial, in the client's interest in instructions giving the jury the option of returning a verdict of guilty of a lesser offense than that charged in the indictment. ${ }^{136}$ A plea bargain is an agreement between the defense and the prosecutor to plead guilty in exchange for a consideration from the prosecutor or judge; the bargain exchanges the defendant's plea of guilty and waiver of trial for the dismissal of other, usually higher, charges, and sometimes a cap on the possible sentence. The lesser included offense issue arises when the jury is instructed at the end of the trial; the court determines whether to give the jury the option of considering whether the defendant is guilty of crimes lower than those charged in the indictment, such as manslaughter in a murder case. Instruction of lesser included offenses tends to increase the chance that the defendant will neither be convicted of the most serious charge nor acquitted in toto; plea bargains, of course, preclude acquittal or dismissal of all charges.

The criminal trial is riddled with uncertainty, but it is not a pure gamble, and a reasonable client will rely enormously on his attorney's advice as to whether to plea bargain or, if going to trial, to seek an instruction on a lesser-included offense. ${ }^{137}$ The danger of the attorney's advice being even unwittingly colored by his or her pecuniary interest in acquittal, seems, at first, clear. Arguably, the general ethical prohibition against conflict of interest encompasses any contingent fee problems, ${ }^{138}$ but the law in general relies upon specific per se rules, such as the ban on criminal contingent fees, to avoid questions of applicability of general rules, such as conflict of interest principles.

A closer look at these conflicts makes the need for a specific ban on criminal contingent fees dubious. Plea bargaining could be hurt

135 See Lester Brickman, Contingent Fees Without Contingencies: Hamlet Without the Prince of Denmark?, 37 UCLA L. REv. 29, 48-49 (1989) and authorities cited.

136 HALL, supra note 114, at 156.

137 See ABA Standards, supra note 43, 4-5.1 at 4.63-.65.

1381 Geoffrey C. Hazard \& W. William Hodes, The Law of Lawyering: A Handbook on the Model Rules of Professional Conduct \& 1.7:101 (2d ed. 1988). 
by a conflict of interest because the contingent attorney might avoid it against the client's interest in his desire to earn his fee through acquittal. But this seems a slight concern in comparison with the conflict that plea bargaining raises with lawyers who have already been paid their entire fee and might advise a poor bargain to be over and done with the case, or with those lawyers who work on an hourly fee and thus would be against even a sound bargain, to keep the meter running. As the New York Court of Appeals has recognized, there is a distinct danger that lawyers who have been paid will be inclined against going to trial, while those who are still earning their pay will be inclined to increase their fee by going to trial, regardless of the client's interests. ${ }^{139}$ Criminal contingent fees thus do not seem to raise any conflicts of interest not raised by plea bargaining within the context of current criminal fee practices.

As for lesser included offense instructions, by the time the attorney must decide whether to request these he will have concluded almost all of the trial. The work will have been done, and the receipt of a contingent fee will depend on a verdict of acquittal. The temptation to gamble with the client's fate seems quite large in the abstract. Against this conflict is a counterweight discussed below; the criminal lawyer's own interest in success. ${ }^{140}$ A lawyer prone to the contingent conflict is the kind who might be tempted toward acquittal anyway by the promise of fame and glory; he or she is a danger regardless of the contingent fee. Moreover, a conflict arising from lesser included offense instructions would be highly visible and so remediable. Lesser included offense instructions can be given only if on a rational view of the evidence the jury could acquit of the "top count" of the indictment and still convict on a lesser, included offense. If this view of the facts is possible, the court has discretion to give the instruction on its own motion, and must give the instruction if the defense so requests. ${ }^{141}$

The harm from a conflict would be the failure of the defense to request the lesser included offense instruction, or even more noticeably, to object to an instruction proposed by the court, but in these events the court could inquire as to the fee arrangement, which is not encompassed within the attorney-client privilege. ${ }^{142}$ A judicial

139 People v. Winkler, 71 N.Y.2d 592, 596, 523 N.E.2d 485, 487, 528 N.Y.S.2d 360, 362 (1988).

140 See, infra, section IV.B.vi.

141 See, e.g., N.Y. Crim. Proc. Law sec. 300.50(1) (McKinney's 1982); 2 Charles A. Wright, Federal Practice and Procedure $\$ 498$ at p. 800 (2d ed. 1982); IV Wharton's Criminal Procedure, $\$ 545$ (Torcia ed. 12th ed. 1976).

14224 Charles A. Wright \& Kenneth W. Graham, Federal Practice and ProceDURE $\$ 5484$ at 370 (1986). There are few, if any, reported cases where such an objec- 
finding that a contingent fee was the probable cause of the opposition could result in the instruction being given despite objection or failure to request. However, the impact of the conflict would arguably remain through the lack of defense advocacy for the instruction in those close cases where the court has not suggested an instruction on its own motion. ${ }^{143}$

Conflict arising out of a supposed economic-based drive toward acquittal has been raised in cases in which convicted defendants claimed they were deprived of the effective assistance of counsel because of contingent fee arrangements. ${ }^{144}$ The courts have given lip service to the conflict theory but have refused to vacate convictions; they demand proof, even in death sentence cases, ${ }^{145}$ that the contingent fee arrangement led to ineffectiveness. ${ }^{146}$

This approach is largely dictated by a Supreme Court general ruling on handling conflict of interest-ineffective assistance claims. ${ }^{147}$

A fuller explanation for not finding ineffective assistance of counsel from a contingent fee violation was recently given by the New York Court of Appeals. The court saw per se vacating of a conviction as a disproportionate penalty for the public and a windfall to the defendant arising from a situation that is hidden (fee-setting) and therefore one against which the state cannot protect itself. ${ }^{148}$ Giving relief to the defendant, the court argued, would arm him and his unscrupulous lawyer with a delayed-trigger weapon to be sprung if the case developed badly. ${ }^{149}$

tion was made, although the lack of cases could indicate, implausibly, that such objections have not in the past been overruled. See, 12A WEST's N.Y.DigeST 3D, CRIMINAL LaW key \# 795(1) (1986); West's Criminal LAW key \# 795(2.90) (WESTLAW). Notably, in the unreported case of United States $v$. Ibn-Tamas, where a new trial was granted because of a contingent fee, there was an objection by the defense to a lesserincluded charge. 407 A.2d 626, 640 (D.C.Ct.App. 1979) (appeal after re-trial); see, infra, note 155 and accompanying text.

143 See supra notes 136-37 and accompanying text.

144 See Schoonover v. State, 543 P.2d 881 (Kan. 1975); State v. Labonville, 492 A.2d 1376 (N.H. 1985); People v. Winkler, 523 N.E.2d 485 (N.Y. App. Div. 1988).

145 Downs v. State, 453 So.2d 1102 (Fla. 1984).

146 See cases cited supra note 144; Cf. Fuller v. Israel, 421 F.Supp. 582 (E.D. Ill. 1976) (no ineffective assistance resulted from agreement with attorney to share in royalties if book about client's murder case was published; client pleaded guilty and claimed plea was in lawyer's financial interest because it kept information for the book from being revealed at a trial).

147 Burger v. Kemp, 483 U.S. 776 (1987).

148 People v. Winkler, 71 N.Y.2d 592, 596, 523 N.E.2d 485, 487, 528 N.Y.S.2d 360, 363 (1988).

149 Id. The defendant's claim of ineffective assistance was ultimately rejected after a hearing on remand, the court finding that the trial strategy was essentially dictated by 
Research has revealed only two cases where a successful claim of ineffectiveness of counsel was premised upon a contingent fee agreement. In the first, United States $v$. Murphy, ${ }^{150}$ the defendant had killed her husband. The attorney-client contract provided that the fee could come out of insurance proceeds that were contingent on acquittal. ${ }^{151}$ The defendant was convicted of first degree murder. Unbeknownst to the defendant, the prosecutor had offered to cap the charge at second degree murder if she pled guilty to murder generally before trial. Defense counsel did not communicate the offer to his client until he knew it was too late, and did not request that lesser-included charges be instructed to the jury. ${ }^{152}$

Stating that "[i]t is hard to imagine a more striking example of blatant conflict between personal interest and professional duty," 153 the court held that the contingent fee contract created a conflict of interest, and that the defendant would have pleaded guilty to second degree murder with proper counseling. ${ }^{154} \mathrm{~A}$ writ of habeas corpus vacating the conviction was granted.

In the second case, United States $v$. Ibn-Tamas, ${ }^{155}$ the trial judge found that during a recess in a murder trial, just before the defendant was to take the stand, the lawyer asked her to sign an agreement under which he would be paid $\$ 70,000$ from life insurance proceeds on the victim-husband. ${ }^{156}$ The client refused to sign, became hysterical and rushed from the courthouse. ${ }^{157}$ That night after much haggling she agreed to pay $\$ 40,000 .^{158}$ Although the client did testify the next day, the court ruled the damage had been done- "the attorney-client relationship was completely ruptured and torn asunder at this direct juncture ...."159 The judge found that payment under the policy was contingent upon acquittal. 160 Although counsel had earlier approached the prosecutor seeking a plea-bargain, he never discussed this with the defendant and never followed up, perhaps because of the fee arrangement. ${ }^{161}$ The court ruled that the

the client and his story. People v. Winkler, Westchester Co. Ct., N.Y.L.J., July 24, 1990, p. 21, col. 6 .

150349 F.Supp. 818 (E.D.Pa. 1972).

151 Id. at 820.

152 Id.

153 Id. at 823.

154 Id.

155 See, Ibn-Tamas v. United States, 407 A.2d 626, 628 n.1, 640-41 (D.C. Cir. 1979).

156 Id. at 640.

157 Id.

158 Id.

159 Id.

$160 I d$.

161 Id. 
right to effective assistance of counsel had been violated and vacated the murder conviction. ${ }^{162}$

Vacating a conviction upon a finding of ineffective assistance of counsel cannot be an effective remedy for contingent fee conflict (if conflict there be), for most such adverse interest representation will not cause the objectively clear ineffective assistance of counsel that courts require to award the relief of a new trial. ${ }^{163}$ It is more practical to ameliorate conflicts, if any, before the harm is done, as is suggested above in connection with lesser included offense instructions being given when the conflict comes to light. ${ }^{164}$

\section{iii. Criminal Contingency vs. Civil Contingency}

Civil contingent fees have long been accepted. Criminal contingent fees are no better or worse than civil contingent fees. Why, then, should criminal contingent fees be prohibited?

If a criminal contingent fee creates a conflict of interest in the ALI "substantial risk" sense, civil contingent fees also cause such conflicts, as where a lawyer might be induced to recommend too low a settlement by the desire to grab a quick fee without much labor, or where a lawyer might wish to try a case to a hopefully larger verdict than a profferred settlement that the client ought to accept. MacKinnon's report on contingent fees stated that there is little objective information on ethical problems arising from the civil fee. ${ }^{165} \mathrm{He}$ noted that the fee arrangement can lead to a disparity between attorney and client in willingness to take a risk on a large recovery as against no recovery at all, but he was unable to provide hard evidence on this point. ${ }^{166}$ MacKinnon also believed that there is usually a convergence of interest of the attorney and the client in the settlement area since a greater settlement increases the recovery for both. ${ }^{167}$ Later commentators, however, found evidence that civil contingent fees reward the lawyer with fast, cheap settlements. ${ }^{168}$

When comparing civil and criminal contingent conflicts, one

162 Id. at $640-41,646$.

163 See Holloway v. Arkansas, 435 U.S. 475, 491 (1978) (multiple representation conflict: “. . to assess the impact of a conflict of interests on the attorney's options, tactics, and decisions in plea negotiations would be virtually impossible."). Contra, Caplin \& Drysdale, Chartered v. United States, 491 U.S. 617, 630 n.7 (1989), discussed infra, Part VI.

164 See supra notes 142-43 and accompanying text.

165 MacKinnon, supra note 21, at 195.

166 Id. at 199.

167 Id. at 196.

168 Murray L. Schwartz \& Daniel J.B. Mitchell, An Economic Analysis of the Contingent Fee in Personal-Injury Litigation, 22 Stan. L.Rev. 1125 (1970). 
immediately notices that the criminal lawyer on straight contingency would not have the civil lawyer's incentive of some fee from settlement to operate as a counterweight to unreasonably gambling on a trial. But the civil conflict inducement is still present. The difference between the civil fee and a criminal contingent fee that depends solely upon acquittal is a matter of degree only, for the civil attorney might still unreasonably push toward a trial in a misguided effort to earn a higher contingency fee than that obtainable from settlement. ${ }^{169}$

One must consider whether the ethical and legal allowance of the civil contingent fee conflict entails that the criminal conflict must be allowed for the sake of consistency. The answer might turn on whether the stakes are too high in criminal cases to permit a conflict acceptable in civil litigation, but the existence of "higher stakes" seems to be an ad hoc, unprincipled criterion, especially given the absence of other regulation aimed at criminal fees. ${ }^{170}$ While many criminal cases do involve higher stakes than civil cases, it is far from clear that this fact should make us wary of allowing criminal contingent fees while civil contingent fees are approved. The "stakes are higher" argument as a supposed reason for banning criminal contingent fees is a reasonable conclusion that the fees could cause problems that are unacceptable in criminal cases, but the apparent force of the conclusion is diluted by the absence of sufficient empirical data on lawyers' actual conduct when operating on a criminal contingent fee.

\section{iv. Contingent Fees vs. Retainers, Hourly Fees, and "Stairstep"}

As was discussed earlier, criminal lawyers commonly seek nonrefundable retainers, but may also work on hourly fees or "stairstep" arrangements where the fee is geared to identifiable litigation stages. ${ }^{171}$ A real-world examination of criminal contingent fees should not assess them in a vacuum, but rather compare them to existing fee arrangments. What is most striking in the criminal defense context is the practice of many clients of paying the entire fee "up front" combined with the high percentage of criminal cases that are settled by plea-bargain. ${ }^{172}$ While plea bargaining is obviously often in the client's interest-defense lawyers have an affirmative

\footnotetext{
169 State v. Labonville, 492 A.2d 1376, 1379 (N.H. 1985).

170 Model Rules, supra note 2, Rule 1.5 .

171 See supra Part IV.A.

172 Chief Justice Burger estimated that about ninety per cent of all defendants plead guilty. See Address of Chief Justice Burger at ABA Annual Convention, N.Y. TIMEs, Aug. 11, 1970 , at 24 , quoted in LAFAVE \& ISRAEL, supra note 55 , at $\$ 20.1$ (c) n.32.
} 
duty to explore plea bargains ${ }^{173}$ - there is always the danger that the plea bargain will be sought against the client's interests. This could happen because the lawyer has already been paid and any further time he spends on a case simply reduces his effective rate. ${ }^{174}$ The supposed dangers of criminal contingent fees pale beside the image of the lawyer gobbling up plea-bargain cases as quickly as possible; at least the "dangerous" contingent fee cases will go to trial.

Hourly fees and stairstep arrangments also lead to inherent conflicts because the attorney's pay depends upon the amount of work he does and the duration of the trial. These fee systems set the stage for conflicts fueled by the attorney's interest in earning as much as possible by running up hours. Oddly, the ABA Standards of Criminal Justice make no mention whatsoever of the conflicts of interest caused by the "orthodox" fee arrangements. ${ }^{175}$

In the absence of data, the reasonable hypothesis is that while contingent fees may create conflicts, they do not create any more conflicts than other widely-used and widely-accepted fee arrangements.

\section{v. Regulating Contingency Conflicts}

Just as civil contingent fees are not banned but regulated, ${ }^{176}$ criminal contingent fees could also be regulated instead of being prohibited. The fee could take into account gradations in the outcome of the case; in that way the attorney would not be risking his entire fee on acquittal, and conflicts arising from the incentive to seek acquittal would be substantially lessened. Regulation could require that a plea bargain could occasion a smaller fee, instead of no fee. ${ }^{177}$ A contingent fee payable on a plea-bargained lesser offense could theoretically cause the lawyer to recommend a poor plea bargain instead of going to trial in a triable case and risking "guilty as

173 ABA Standards., supra note 43, Rule 4-6.1.

174 Ryan L. Petty, Fee-Setting and Fee-Collection Practices among Criminal Defense Attorneys in the State of Texas 5, 6 (Fall 1973) (unpublished manuscript, on file with the University of Texas Law School Library) noted in Albert W. Alschuler, The Defense Attorney's Role in Plea Bargaining, 84 YALE L.J. 1179, 1200 (1975); see also, How to SET FeEs, supra note 112, passim.

175 ABA STANDARDS, supra note 43, Rule 4-1.6 states that the client's interests are paramount and personal advantage should not influence the lawyer's performance, but the reference is to an attorney's aggrandizement through publicity, not financial arrangements. Id. at Rule $4.22 \mathrm{cmt}$. See also, id. at Rule 4-6.1(b); id. at Rules 4.70-.73 cmt. (remarks on exploring plea bargaining do not mention financial conflict of interest); id. at Rule 4-5.2(a) (client decides what plea to enter); $i d$. at Rules $4.66-.67 \mathrm{cmt}$. (silent re conflict).

176 Gair v. Peck, 160 N.E.2d 40 (N.Y. App. Div. 1959), cert. denied, 361 U.S. 374 (1960). 177 Charles W. Wolfram, Modern Legal Ethics 538 (1986). 
charged" thereby foregoing any fee, but this danger seems much less real than the possibility of a lawyer's pleading a client guilty under a move to grab a quick nonrefundable retainer.

Regulation could also require that any contingent arrangement be disclosed to the court. In this manner, the trial judge could make sure the client understands the ramifications of possible conflicts of interest. This is analogous to the current practice of giving detailed explanations of his or her rights to a criminal defendant who pleads guilty, even though the defendant's lawyer presumably has already explained this. ${ }^{178} \mathrm{~A}$ similar conflict also arises in the settlement of class actions, where a plaintiff's attorney stands to recover attorney's fees from the defendant directly or out of the recovery for the class. The class action conflict is handled by requiring the court to approve the settlement. ${ }^{179}$ Requiring judicial approval of pleas in forfeiture cases would enable the judge to inquire sharply of the prosecutor as well as the defense attorney to uncover any deal-making in derogation of the client's interest.

The Supreme Court's recent assertion ${ }^{180}$ that any problems arising out of a contingent fee can be handled by vacating the conviction for ineffective assistance of counsel unsatisfactorily places the matter after the fact, when courts are disinclined to "unscramble the omelet" and subtle issues of fact such as motivations of attorney and client must be imperfectly resolved. ${ }^{181}$ Judicial inquiry before the plea or jury instructions would tackle the contingency problem at a time when the process can still help the defendant.

\section{vi. Critique of the Conflict Rationale}

What is missing from discussions of criminal contingent fees and conflict of interest is the psychology of litigators-their intense desire to obtain the best result their skills can achieve. Conflict of interest analysis should not woodenly proceed without account of the criminal lawyer's ever-present motive to obtain a better-thanexpected result. This strong motive is what keeps the attorney's and client's interests united, contingent fee or not. Only an attorney who is a general danger to the public, contingent fee or not, is going to accept a poor result in the case for the sake of the fee; this proposition follows from the psychological disposition of criminal lawyers.

178 Fed. R. Crim. P. 11 (c),(d); see also, Boykin v. Alabama, 395 U.S. 238 (1969).

179 Fed. R. Civ. P. 23(e); see also, 7B Charles A. Wright, Arthur R. Miller \& Mary K. Kane, Federal Practice and Procedure sec. 1797.1 (2d ed. 1986) (court alert to conflict of interest problems).

180 Caplin \& Drysdale, Chartered v. United States, 491 U.S. 617 (1989).

181 See supra notes $163-64$ and accompanying text. 
Lawyers who would sacrifice the client for a contingent fee are so corrupted that they are a hazard to their client regardless of the fee arrangement.

This is not mere intuition or fantasy. The New York Court of Appeals, surely no den of naivete, believes that fixed fee and hourly fee conflicts are avoided mostly by attorneys' honor and fidelity to their responsibilities. ${ }^{182}$ This thought is easily applicable to contingent fee "conflicts."

Given the unlikelihood of acquittal in most cases, the conflict rationale for the contingent ban is based on an unnecessarily paranoid premise. Those few cases that any single lawyer would take on a straight acquittal-contingency basis will appear so strong that the client's interest will normally lie in attempting to obtain an acquittal. ${ }^{183}$ The fee will spur the attorney on to complete the enormous amount of preparation required for cases going to trial. 184 There just won't be straight acquittal-contingent fee arrangments in cases with less than an exceedingly strong likelihood of acquital. If it becomes apparant, during the course of the trial, that the fee arrangement is unwise for the attorney because acquittal is improbable, the attorney is not going to fight a quixotic battle for this improbable acquittal in an attempt to earn a fee. By hypothesis, the attorney stands a slim chance of earning the fee that way, and in the process he or she practices bad law with all the unpalatable consequences for him or her that that entails.

Whether to ask for lesser-included offenses at a time when the attorney has already done nearly all of the trial work and sees his or her fee hanging on an acquittal is more problematic. Here again, however, any sense of decency the lawyer has will prevent him or her from sacrificing the client and reputation to a conviction on the top charge. Because few cases are likely to be attractive to lawyers on a pure acquittal-contingency basis, the attorney's interest will lie in a graduated contingency arrangement. This interest is in accord with the client's in seeking a lesser-included offense instruction (or, for that matter, a plea-bargain). As it is, clients are probably the largest source of objection to lesser-included charge instructions anyway. ${ }^{185}$

182 People v. Winkler, 71 N.Y.2d 592, 523 N.E.2d 485, 528 N.Y.S.2d 360 (1988).

183 But cf. People v. Winkler, 128 A.D.2d 153, 163, 515 N.Y.S.2d 488, 495 (1987), rev'd on other grounds, 71 N.Y.2d 596, 528 N.Y.S.2d 360 (1988) (change in strategy may be warranted as litigation progresses).

184 Wolfram, supra note 177 , at 537.

185 Whether to seek a lesser included offense instruction is the client's decision to make. ABA STANDARDs, supra note 43 , Rule $4-5.2 \mathrm{cmt}$. at 4.68 . 
In the final analysis, all statements to date (including those in this Article) about contingent criminal fees are necessarily speculative. One could therefore conclude that the burden of proof on those who would continue the ban has not been satisfied according to empirical requirements. While this approach might seem not to give weight to the collective wisdom of the rule-makers, experienced attorneys and judges who are often allowed to form opinions without formal empirical evidence, the worth of what the bench and bar believe without formally compiled data is questionable. For example, when the Supreme Court found televising of trials to be unconstitutional it noted the ABA Judicial Canons prohibition ${ }^{186}$ and stated that television would infect the trial in various horrible ways which the Court detailed at length. ${ }^{187}$ When, seventeen years later, the Court about-faced and permitted televised trials, it noted that "no one has been able to present empirical data sufficient to establish that the mere presence of the broadcast media inherently has an adverse impact on that process." 188

The real problem is that the ban on criminal contingent fees is propped up not just by the conflict of interest argument but by other specious rationales, and by a calcified and mostly unquestioned tradition. ${ }^{189}$ Only after those other rationales are discarded and an experimental allowance of contingent fees begins will a forthright assessment of the conflict of interest problem be made.

\section{SUPPOSED IMMORALITY OF THE CRIMINAL BAR AS A REASON FOR THE BAN}

More than one commentator has opined that the true basis for the contingency ban is the image of the criminal lawyer as a lesser moral breed than his civil peers. 190 This "rationale" is hardly more than a group libel. Judging groups of people adversely derogates not only a national policy not to discriminate, but also common

186 Estes v. Texas, 381 U.S. 532, 535 (1964).

187 Id. at 545-49.

188 Chandler v. Florida, 449 U.S. 560, 578-79 (1981). Compare Perry v. Leeke, 488 U.S. 272 (1989) (it is an "empirical predicate of our system" that permitting a witness to consult with counsel after direct but prior to cross-examination is less likely to lead to discovery of truth, even assuming no witness deceit.) with Chandler at 605 (Marshall, J. dissenting) (majority provides not "a shred of evidence" to support its "empirical predicate.").

1891 Geoffrey Hazard, Jr. \& W. William Hodes, The Law of Lawyering: A Handbook on the Model Rules of Professional Conduct sec. 1.5:501 (1990) ("The rule against contingent fees in criminal cases has been 'traditional' for so long that it has few serious opponents.").

190 Wall, supra note 117, at 3; see also, Brickman, supra note 135, at 40-41, and sources cited therein. 
sense. Disparagement of the criminal bar as a basis for its regulation is doubly wrong because the negativism often rests on an impermissible identification of the lawyer with his criminal clients. ${ }^{191}$ Moreover, it is wrong because, at the time the contingent fee arrangement is entered into, the client is only an accused, not an adjudicated criminal. In comparison, the civil contingency bar, which is sometimes euphemistically accused of "building a case"-making up evidence-would not be immune in a name-calling contest. ${ }^{192}$ In general, the criminal bar fee practices outlined earlier do not bespeak a character defect when compared with civil fee practices, which commonly include padding up fee hours and charging "what the traffic will bear."193

Certainly the early courts that prohibited recovering on criminal contingent fee contracts seemed to despise what criminal lawyers do, if not the criminal lawyers themselves. The court in Weber $v$. Shay ${ }^{194}$ expressed the thought that heading off an indictment was against public policy regardless of the means used. The case did not involve a contingent fee contract, but through its prominent citation by MacKinnon it has served as a legal cornerstone for the criminal contingent fee ban. ${ }^{195}$ Peyton $v$. Margiotta ${ }^{196}$, also cited by MacKinnon, held that assistance in obtaining a pardon on a contingent fee was improper, but the court did not emphasize the contingent fee as the problem, relying instead on a precedent involving pardons. The Peyton court cited reasoning in the precedent that one cannot purchase a pardon by paying off the governor, and held that a lawyer cannot "bribe" others to deceive the governor to obtain a pardon. ${ }^{197}$ Thus, all contracts to obtain pardons by use of money, even to pay for a lawyer's services, were held void. ${ }^{198}$

Other contingent fee cases cited by Peyton conjured up a danger of contingency inducement to sinister acts as a matter of mere judicial surmise. ${ }^{199}$ The court in Ormerod v. Dearman ${ }^{200}$, a contingent fee

\footnotetext{
191 Brickman, supra note 135 , at 40.

192 MACKinNon, supra note 21, at 200.

193 Susan Beck \& Michael Orey, Skaddenomics, AM. LAw., Sept. 1991, at 3; Billing: Is Padding Widespread?, 76 A.B.A.J. 42 (Dec. 1990); Lisa G. Lerman, Lying to Clients, 138 U. PA. L. Rev. 659, 705-20 (1990); Stephen Labaton, Lawyers Clash on Plan to Hear Asbestos Cases, N.Y. Times, May 31, 1991, at D2 col. 5.

19446 N.E. 377,380 (Ohio 1897).

195 See MacKinnon, supra note 21, at 52; Trial Lawyer's Code of Conduct, supra note 107.

196156 A.2d 865, 868 (Pa. 1959).

197 Id. at 867 (citing Hatzfield v. Gulden, 7 Watts 152 (Pa. 1838)).

198 Id.

199 See Peyton v. Margiotti, 156 A.2d 865 (Pa. 1959).

$200100 \mathrm{~Pa}$. 561, 563 (1882).
} 
case, thought it deeply wrong for an attorney to settle a fornication prosecution with the client's payment to the complaining husband. The Restatement (First) of Contracts placed its ban on criminal contingent fees in the subdivision on "Bargains Tending To Obstruct the Administration of Justice." 201 And in contemporary times, the New York Court of Appeals went so far as to express worry that criminal lawyers would enter into contingent fee contracts so as to be able to torpedo convictions on the grounds of ineffective assistance of counsel. This last court paints a portrait of the criminal lawyer with an atomic bomb strapped to his back, ready to damn himself in open court as both ineffective and unethical, just for the sake of winning one (last) case. ${ }^{202}$

Popular folklore distrusts criminal lawyers, but then again popular folklore distrusts all lawyers. ${ }^{203}$ Throughout history many lawyers, including criminal practitioners themselves, have viewed criminal lawyers askance, questioning the need for a criminal bar altogether, ${ }^{204}$ and finding the notion of a treatise on criminal practice ethics jocular. ${ }^{205}$ Prosecutors often think that criminal lawyers are of criminal morality, especially those who appear in organized crime cases. ${ }^{206}$ Recent legislation and prosecutorial policy leading to inquiries of criminal lawyers regarding their fees shows that criminal lawyers are still generally viewed as less than trustworthy. ${ }^{207}$

What bothers those who premise opposition to criminal contingent fees upon the immorality of the criminal bar is the inducement to subornation of perjury and other obstructions of justice in the supposed singleminded drive toward acquittal. ${ }^{208}$ An answer to this concern was given in a civil context by an ABA delegate in 1908 when the Canons of Ethics were being debated:

The contention that there is any more perjury or subornation of perjury in cases prosecuted upon contingent fee contracts than in those in which that feature is wanting, or than there is in the defense of such

201 Restatement (First) of Contracts secs. 540-558 (1933).

202 People v. Winkler, 71 N.Y.2d 592, 523 N.E.2d 485, 528 N.Y.S.2d 360 (1988).

203 Wall, supra note 117 , at 3.

204 George W. WARrelle, Legal Ethics 145 (2d ed. 1920), quoted in Wall, supra note 117 , at 3.

205 John M. Burkoff, Criminal Defense Ethics v (1989) (author told "it should be a pretty short book.").

206 David W. Louisell, Criminal Discovery: Dilemma Real or Apparent?, 49 Cal. L. REv. 56, 99 (1961).

207 See Tarlow, supra note 119, at 45; Zimmermann \& Lavine, Attorney Subpoenas Imperil Choice of Counsel, Apr. Trial 51 (1990).

208 ABA STANDARDS, supra note 43, at Rule 4.37 ("corrupt tactics"; "danger of abuse"); see also Robert H. Aronson, Attorney-Client Fee Arrangements: RegulaTION AND REVIEW 97 (1980). 
actions, rests solely in assertion. Repetition has gained for it some measure of acceptance without any kind of competent proof. ... What reason is there to believe that any lawyer, whose moral stamina would otherwise have maintained him in uprightness, will yield under the added influence of the fact that he gets a fee only in case his client prevails? ${ }^{209}$

As one eminent commentator has pointed out, the inducement to perjury argument misconceives the risks involved on the one hand, and existing pressures to commit perjury on the other. ${ }^{210}$ It can also be hypothesized that the criminal bar is less subject to pressures to litigate criminally than the civil bar because criminal lawyers are under the watchful gaze of prosecutors and law enforcement personnel as their case wends it way through the system.

The reasonableness of blanket distrust of the criminal bar as a posture has been questioned by commentators ${ }^{211}$ and lawyers. ${ }^{212}$ As with susceptibility to conflict of interest temptations, the supposed immorality of the criminal bar is a popular notion that simply is not grounded on formal evidence. It may be that the distrust of the criminal bar as a basis for the contingent fee ban is a socially acceptable substitute for distrust of law enforcement personnel. Prosecutors and policemen work for a government salary, and for this reason-if one is inclined to join the morality speculatorsmight be thought to be especially vulnerable to corruption attempts, perhaps more than civil contingent lawyers' counterparts, insurance lawyers whose incomes are often fairly large.

Supposed lack of moral fiber in the criminal bar as a reason for special regulation is an historical prejudice, anachronistic in an age that rejects "groupthink." The prejudice is also a hangover from the days of associating the "mouthpiece" lawyer with his client in an effort to disarm the client by denying that his lawyer is an independent moral agent. ${ }^{213}$ Currently the prejudice may be more a projection by the bar of what the public fears criminal lawyers will do to earn their fees than a belief held by the bar leaders themselves. ${ }^{214}$

209 ABA REPORTS, supra note 85, at 71, 73-75 (speaker was against the canon because it provided for judicial supervision of the fee.).

210 Wolfram, supra note 177 , at 537.

211 Id. at 537-38. See also, Brickman, supra note 20, at 29; HazARD \& Hodes, supra note 189 , at 84 (incentive for perjury in civil actions as well).

212 Wall, supra note 117 at $3,4$.

213 ABA Standards, supra note 43, 4-1.1 at $4.9 \mathrm{cmt}$.

214 Eugene R. Gaetke, Lawyers as Officers of the Court, 42 VAND. L.Rev. 39, 60 n.106 (1989). 


\section{MiSCELLANEOUS REASONS}

Several additional reasons have been given for the ban on criminal contingent fees. These reasons prove to be even less compelling than conflict of interest and inducement to corruption.

\section{i. Lack of Res}

One argument often advanced against criminal contingent fees is that, while a successful plaintiff's civil suit produces a res with which to pay the contingent fee, there is no res produced in a successful criminal defense. Civil contingent fees, however, are permitted in cases that do not produce a res, such as defense work. ${ }^{215}$ Moreover, a successful criminal defense can produce a res, in the form of life insurance or an estate that the client, having been exonerated, may inherit, ${ }^{216}$ illegally seized funds returned to the client, ${ }^{217}$ the right to commercialize the client's story ${ }^{218}$, or even a productive worker-the freed client himself. ${ }^{219}$

The fundamental problem with the res rationale is that it is illogical. While a produced res enables the civil plaintiff to pay his attorney, there are ways of paying a lawyer without a produced res, in particular from the client's assets. Notably, the res rationale was added to the ABA Model Code ban on criminal contingent fees after the tentative draft. ${ }^{220}$ The 1968 draft had simply stated that "[p]ublic policy properly condemns contingent fee arrangements in criminal cases"-without identifying the policy or mentioning a res. 221

215 See, e.g., Nassau County (Long Island, N.Y.) Bar Comm. on Ethics and Professional Responsibility Op. 90-12, reported in April 17, 1990 N.Y.L.J. 6 (1990). A lawyer representing a defendant in a civil action for forfeiture of assets as proceeds of a crime (N.Y. Civ. Prac. L. \& R. secs. 1310-56 (McKinney 1990)) inquired if he could work on a contingent fee. The Bar Association approved the fee because it was a civil action. See generally, Annotation, Validity, Construction, and Effect of Contract Providing for Contingent Fee to Defendant's Attorney, 9 A.L.R.4TH 191 (1981).

216 See, e.g., United States v. Murphy, 349 F.Supp. 818 (E.D. Pa. 1972); Schoonover v. State, 543 P.2d 881 (Kan. 1975).

217 See Wall, supra note 117 , at 3, 4 .

218 See BURKoff, supra note 205, at 11-8 n.15. "Son of Sam" laws may prohibit this. See N.Y. Exec. Law sec. 632-a (McKinney 1982). See, e.g., Children of Bedford, Inc. v. Petromelis, 77 N.Y.2d 713, 573 N.E.2d 541 (1991). Moreover, acquisition of publishing rights prior to the conclusion of a case might be unethical. ABA STANDARDs, supra note 43, at Rule 4-3.4.

219 Brickman, supra note 20, at 41. See also Wall, supra note 117 , at 3, 4 .

220 American bar foundation, Annotated Code of Professional Responsibility 108 (1979).

221 Id. 


\section{ii. "Necessary Evil"}

Another argument that has been advanced is that while contingent fees are a necessary evil to enable indigent civil litigants to hire a lawyer, ${ }^{222}$ indigent criminal defendants will have a lawyer appointed free of charge by the court. The contingent evil, this argument goes, is therefore not necessary. ${ }^{223}$ This argument is flawed because it rests on the assumption that criminal defendants choosing to utilize a contingent fee will be entitled to court-appointed counsel. That is not necessarily the case. For just as civil litigants capable of paying an hourly rate sometimes choose to utilize a contingent fee, so too may similarly situated criminal defendants. Indeed, the very fact that civil contingent fees are permitted even in cases where the client can afford an hourly rate ${ }^{224}$ belies the contention that contingent fees are an evil to be avoided where possible.

In point of fact, not only can anything said against the criminal contingent fee be equally said against the civil contingent fee, but a lot more can be said against the latter: Criminal lawyers cannot, like civil lawyers, go around creating or pumping up frivolous cases. The "necessary evil" argument, even when seasoned with the notion that "criminal stakes are higher," 225 is more a debating point than a ground for the contingent fee ban.

\section{iii. Overreaching}

It could be argued that contingent fees are overreaching in that the criminal client is too scared and desperate to turn down what an attorney offers him in the way of an unreasonably high contingent fee. It is hard to imagine, however, how contingent fees could overreach any more than, or as much as, the present system with its reliance upon the attorney's self-interested judgment as to what is a "reasonable" fee. As one judge has stated, "the range of fees for handling pleas of guilty is especially wide, and it is inexplicable in terms of any rational distinctions .... One lawyer may charge five or ten times what another lawyer would . . ."226

The possibilities for overreaching are not especially characteris-

222 See ABA Standards, supra note 43, at 4.37; Richard M. Birnholz, The Validity and Propriety of Contingent Fee Controls, 37 UCLA L. REv. 949, 953 (1990).

223 F.B. MacKinnon, supra note 21, at 53; See also, ABA Standards, supra note 43, at Rule 4.37.

224 Brickman, supra note 20, at 43; Model Code, supra note 4, at EC 2-20.

225 See supra, Part IV.B.iii.

226 United States v. Vague, 521 F.Supp. 147, $154-55$ (N.D. Ill. 1981) (court sua sponte reduces fee). See also United States v. Vague, 697 F.2d 805 (7th Cir. 1983) (court had no power to reduce fee; contempt finding against lawyer reversed). 
tic of a contingent fee, certainly not when compared with an hourly arrangement, which naturally induces hour padding, or with a stairstep fee, which creates a similar incentive to prolong litigation. Indeed, problems caused by contingent fees and hourly and stairstep arrangements all pale beside those generated by the common criminal defense practice of obtaining a nonrefundable retainer. ${ }^{227}$

227 ABA rules require the lawyer to take into account "the time and labor required" as a first factor in setting a fee. Predictions to the client as to how much time and labor will result after an hourly agreement or "fixed amount," as distinguished from an "estimated amount," are not mentioned in the Rule or commentary, Model Rules, supra note 2, at Rule $1.5 \mathrm{cmt}$. The basic rate can be an "estimated amount," but there is no requirement to mention an estimated number of hours if an hourly charge is decided upon, and it is only the "estimated amount" that must be revised in the event of a change in circumstances. Id. The ABA's current ethics code states in a comment that if the fee is paid in advance, the unearned portion should be returned, but apparently this is a reference to terminations of the attorney-client relationship by attorney withdrawal. Id. The comment confusingly cites the ethics provision dealing with termination by withdrawal of the attorney, not termination by any completion of the attorney-client relationship. See, Id. at Rule 5.4. The previous ABA ethics code also explicitly mandated return of unearned fees in the context of an attorney who withdrew from employment. MODEL CODE, supra note 4, at DR 2-110(A)(3). Presumably there would not be a need for specific regulation in the withdrawal context if all attorneys, withdrawing or not, had to return unearned fees at the conclusion of the representation.

The subject of returning unearned fees is confused by a distinction between specific retainers, applicable to specified services, and general retainers, which pay for what amounts to an option on the lawyer's services, reserving his time, and precluding him from getting involved with other clients whose interests are in conflict with the retaining client. Lester Brickman \& Lawrence A. Cunningham, Nonrefundable Retainers: Impermissible under Fiduciary, Statutory and Contract Law, 57 Ford. L.REv. 149, 157-59 (1988). The current provision is Model Rules of Professional Conduct Rule 1.5(a). Some ethics opinions indicate that a nonrefundable retainer is proper so long as it is reasonable, Disciplinary Board of Hawaii Supreme Court Op.29 (1985) reported in ABA/BNA MANUAL, supra note 102, at 801:2802 at 30, or complies with DR 2-106 of the MODEL CODE OF Professional Responsibility as not being illegal or clearly excessive. Other opinions ban nonrefundable retainers per se, Kansas Bar Association Op. 84-12 (1984) reported in ABA/BNA MANUAL, supra note 102, at 801:3819 at 45. If any fees must be returned under ABA strictures it is unearned fees, Bar Association of Nassau County (New York) Op. 85-5 (1985), reported in ABA/BNA MANUAL, supra note 102, at 801:6208 at 45; ABA Comm. on Ethics and Professional Responsibility Informal Op. 998 (1967), reported in 2 ABA Informal Ethics Opinions 161, 165 (1975). Also, the opinions consider an amount paid to option the attorney's services as an earned fee. Bar Association of Greater Cleveland Op. 84-1 (1984), reported in ABA/BNA MANUAL, supra note 102, at 801:6952 at 94. This fact must be explained to the client. Model Rules, supra note 2, at Rule 1.5(a)(2). More than one ethics opinion has taken the position that how much must be returned as "unearned" is not an ethics question at all. State Bar of Arizona Op. 262 (1969), reported in Olavi Maru, 1970 Supplement to the Digest of Bar Association Ethics Opinions \#6016, p. 134 (1974); ABA Comm. on Ethics and Professional Responsibility, Informal Op. 916 (1966), reported in 2 ABA Informal Ethics Opinions 64 (1985).

An ABA opinion clearly endorses keeping unearned retainers that do not involve options. ABA Comm. on Ethics and Professional Responsibility, Informal Op. 1389 (1977), reported in ABA Formal and Informal Ethics Opinions 278 (1985): "There is nothing improper in a lawyer charging and being paid a fixed fee in advance for legal 


\section{Against this backdrop of existing "ethical" fee-setting practices, it strains the imagination to see contingent fees as overreaching. ${ }^{228}$}

work on tax matters or litigation before the Tax Court if . . . the fixed fee embraces all work to be done, whether it be relatively simple and of short duration, or complex and protracted." Id. This statement seems to approve a fixed fee that results in much less than the onerous work that was potentially present and paid for. The opinion was in response to the question whether it was proper to charge a fixed fee for tax planning "which would also cover representation of the client in the event of . . audit . . . and in possible litigation before the Tax Court. If either the audit or the Tax Court litigation did not ensue, the lawyer would keep the fee." Id. (emphasis added). Perhaps this ethics opinion assumes that the lawyer has presented to the client an honest assessment of the chances of audit and litigation, so that the client knows the probability of the lawyer having to do extensive work beyond the tax planning.

228 There is not much case law on the legality of nonrefundable retainers. See, Brickman \& Cunningham, supra note 227, at 150. The highest court of New York recently dealt with the issue in one case with inconclusive results, holding that the particular agreement was ambiguous and so it was unnecessary to reach the question of whether nonrefundable retainer agreements were legal. Jacobson v. Sassower, 488 N.E.2d 1283, 1284 (N.Y. 1985). A matrimonial client agreed to a non-refundable retainer of $\$ 2,500$, and prior to trial discharged the attorney without cause. Jacobson v. Sassower, 452 N.Y.S.2d 981, 982 (N.Y.C. Civ. Ct. 1982). She sued to recover $\$ 1,500$ as unearned fees. Id. The trial court found for plaintiff on the ground that the fee contract improperly penalized the client for exercising the right to discharge the attorney, holding the fee was a "special retainer", i.e., an advance fee for future services, not a "true" or "general retainer", for services during a fixed period and intended to compensate the attorney for being conflicted out of representing anybody else in the case. Id. at 984 . The court placed reliance on the absence of contractual language designating the $\$ 2,500$ as a "minimum fee." Id at 985 . The court stated that if services are continued to "completion" the client has no claim to refund. Id. at 982. But what if "completion" includes, as this contract seemingly provided for, reconciliation of the spouses. The court was silent on this point, since there was no reconciliation, but a difference in result because of spousal reconciliation would allow non-refundable retainers of substantial size without substantial labor.

The Supreme Court, Appellate Term affirmed the Civil Court's holding by a vote of 2-1. The court stated the attorney was relegated to recovery of the fee on a quantum meruit basis for services rendered, while noting the lawyer's argument as to the propriety of nonrefundable retainers as "demonstrated by their widespread use, especially among attorneys practicing matrimonial and criminal law." Jacobson v. Sassower, 474 N.Y.S.2d 167, 169 (N.Y. App. Term 1983)(per curiam). Again, the court discussed the issue only in the context of discharged attorneys. Id. The dissent would have placed the burden on the client to show unreasonableness or unfairness of the fee agreement. Id. at 171 (Parness, J. dissenting).

Next, the Appellate Division affirmed 4-1 in a brief opinion on the ground the retainer agreement was ambiguous. Jacobson v. Sassower, 483 N.Y.S.2d 711 (N.Y. App. Div. 1985). The court stated that whether such retainers are uneforceable as unconsciounable or as chilling the right to discharge the attorney depends on the facts of the particular case: "[s]uch retainers, while not to be encouraged, are not, in all cases, unenforceable as a matter of law." Id. at 712. The dissent said the contract was clearly like a "requirements contract" under which the attorney was obligated to supply all the specific services the client needed during a certain period, and the attorney was thus committed to providing such services. Id. (Kupferman, J. dissenting). Absent unconscionability, the nonrefundable retainer clause was not per se invalid, and the very contract in the case had been held ethical in a grievance proceeding. Id.

Finally, the Court of Appeals also affirmed, supra, on the ground the agreement was 
If overreaching actually proved to be a problem in practice, courts or legislatures could set maximum contingent fee structures just as is now done with civil plaintiff contingent fees. ${ }^{229}$ Civil maximums are percentages of the recovery; criminal maximums could be based upon what lawyers generally charge those who are not rich or involved in the most difficult cases. There could be a substantial "kicker" in the regulated fee because of its contingency. Lawyers who did not like the maximums could, of course, turn down contingent fee cases. In sum, overreaching, if it arose, would present challenges easily mitigated by regulation.

A different issue is whether a contingent fee would be a poor use of resources for the client. There is no ethics question here, for the codes only prohibit "[un]reasonable" legal fees, and a contingent fee is not per se unreasonable any more than a nonrefundable retainer ${ }^{230}$ or an hourly fee. ${ }^{231}$ Unless and until criminal contingent fees are validated and data accumulated, there is no $a$ priori way of saying that they are less "reasonable" than nonrefundable retainers or $\$ 350$ an hour charges. Clients, patients, investors, and people generally are permitted to take risks in this country, and the fee arrangement in a criminal case, where going to trial itself can be a considerable risk, does not appear to deserve unique paternalistic supervision.

\section{iv. Misleading the Client}

Another argument against the criminal contingent fee is that it misleads the client. One court has said that:

The attorney, by accepting a criminal case on a contingent fee basis makes it appear to the client that he is using personal influence, or something worse, to manipulate the judicial system in order to obtain the promised result. This may lead the client to conclude that the judicial system is susceptible to manipulation. Fostering such beliefs is prejudicial to the administration of justice. ${ }^{232}$

A high retainer, however, could foster the same impression of

ambiguous and the client may not have understood it. Jacobsen v. Sassower, 488 N.E. $2 d 1283$ (N.Y. 1985). Therefore, it was "not necessary to reach plaintiff's further contention that nonrefundable retainer agreements are against public policy and, therefore, void." Id. at 1284-85.

229 See, e.g., 22 N.Y. Comp. Codes R. \& Regs. Chapter IV, Article I, subarticle A, part 600 , sec. 603.7(e)(2) (1986) (setting maximum contingent fee in personal injury and wrongful death cases).

230 See supra note 227.

231 Model Rules, supra note 2, at Rule 1.5(a).

232 Louisiana State Bar Ass'n v. Nader, 472 So.2d 11, 13 (La. 1985) (disbarment for, inter alia, entering contingency fees, including promise to refund fee if given result not obtained.). 
corruption. In fact, it is not clear why the contingent fee fosters the impression of "buying justice" at all. It is logically possible that a client might perceive the contingent lawyer's confidence as based upon the lawyer's secret, sinister, sure-fire plan to win the case. Precisely the same misconception is possible for any client faced with a demand for a large retainer; the client could believe that the retainer is to be divided between the lawyer and a key official. Under a contingent fee system, obtaining a fee depends upon obtaining a favorable result, which makes having the case "in the bag" extremely important to protect the lawyer, or so the client might think. Against this belief, lies the obvious fact that a crooked lawyer is not likely to lay out his own money in advance to finance a bribery plot, a presumed necessity in an imagined corrupt contingent fee. Whether clients would be misled into believing that lawyers charging contingent fees possess a special touch their fellow mortals at the bar do not, is no more an ethics question than is that of whether people who select superstar attorneys by their media reputation are making a sound decision.

\section{v. Protection of the Bar}

One commentator has suggested that the true goal of the ban on criminal contingent fees is the prevention or restraint of competition from lawyers who might not collect the fee in advance. ${ }^{233}$ Given the comparative rarity of cases that lawyers would want to take on a contingency basis, this conspiracy theory seems even less believable than the typical conspiratorial concerns.

Another commentator envisions the ban on contingent fees as a means of forestalling the public perception that lawyers profit directly from frustrating law enforcement. ${ }^{234}$ This reason for prohibiting contingent fees should not be reflexively brushed off as just another conjecture on poor public relations. If a lawyer earns money because of an acquittal he is profiting from crime in a manner fundamentally different from the other players in the criminal justice system who process and prosecute criminals. The contingent fee enriches the lawyer just because the crime has been made, with his assistance, "perfect"-the client has gotten away with it. (That a not-guilty verdict is suggestive of innocence in fact does not necessarily carry much weight with observers.) Contingent fee lawyers would gain from crimes being committed and going unpunished-this

233 Thomas D. Morgan, The Evolving Concept of Professional Responsibility, 90 Harv. L. REv 702, 734 (1977); See also, Gaetke, supra note 214, at 60 ("unified and perpetual front" against other fees clients might prefer).

234 Paul D. Carrington, The Right to Zealous Counsel, 1979 Duke L.J. 1291, 1307 (1979). 
public perception might indeed be too much for the bar. ${ }^{235}$

\section{The Niche For Contingent Fees}

Assuming that criminal lawyers generally strive to get paid in advance, the question arises whether abandonment of the prohibition of contingent fees would make any difference to any lawyer but the youngest, hungriest, and most desperate for work. One response to this query is a market explanation. Practical differences from repeal of the ban are immaterial: If the ban is unsupportable, general free market principles are sufficient to justify repeal. Another response is to simply postulate that, at the margins, at least some lawyers and defendants would prefer contingent fees, and so repeal would make a difference.

I suggest that there is a large class of clients who would find contingent fees attractive, and that the size of this group in the marketplace might well attract attorneys willing to take at least occasional gambles on total or partial ${ }^{236}$ contingency fees. A rich client might demand that the lawyer work on a contingent fee, but lawyers will find this unattractive in a case where the client is eminently able to shell out without being guaranteed a result in the case. Poor clients, of course, are in no position to pay contingent fees. But the middle class might find contingent fees very suitable, and its very size would cause some lawyers to take the chance in suitable cases.

If one hypothetically stops the average middle class person on the street and asks if he or she would rather pay a lawyer only if the lawyer obtains a favorable result, the answer will be an enthusiastic "yes." Such persons cannot afford to purchase the services of famous lawyers, but they do have reasonably substantial assets. A member of the middle-class will be willing to part with a considerably larger portion of these assets if he or she obtains something tangible in return; acquittal or avoidance of a lengthy prison sentence. Mere "professional services" are of little value. The average person also believes that a contingent fee increases the lawyer's zeal. ${ }^{237}$

A common situation illustrates this point. A young man faces a serious charge such as homicide or armed robbery. His family is not at all happy at the prospect of paying $\$ 15,000$ in advance for legal

\footnotetext{
235 It is at least logically possible, in fact, that some of the opposition to criminal contingent fees comes from those who understand that contingent fees would improve criminal defense representation-an unpleasant thought for many.

236 Partial contingency fees are prohibited by the ethics ban. New York State Bar Op. 412 (1975), reported in Olavi Maru, 1975 Supplement to the Digest of Bar AssociaTION ETHics OpINIONS Op. 9172 (1977).

237 Carrington, supra note 234, at 1293.
} 
representation of an indefinite nature leading to an unpredictable result. Two or three thousand dollars probably seems about right to them. The family would, however, happily sacrifice twice as much as the $\$ 15,000$ demanded by the well-regarded lawyer if their son returned to them without having to go to prison at all, or for only a few years. It is also not hard to imagine an honorable attorney willing to take this chance with them, having sympathy for the client's desire to avoid assigned counsel but being unwilling to take the case on the comparatively paltry fee that the family was willing to advance. Such an attorney might have dozens of pending cases of various sizes; a few contingency files in the office would spice things up by virtue of both the gamble and the prospect of a larger than usual fee.

Obviously, collecting contingency fees is as important to lawyers as collections under traditional fee arrangements. Contingent fees could be secured through a mortgage, or funds placed in escrow. Naturally, this would have to be done at the time the retainer agreement is executed.

Agreements could provide for a combined partial contingency fee and partially reduced retainer or reduced hourly rate. The agreement might also provide for a lower fee for a result less favorable than acquittal. ${ }^{238}$ A client would not feel compelled to turn down a plea bargain in order to save this lesser contingent fee for he would owe even more money if he went to trial and were acquitted. In any event, minimizing prison time would likely be more important to him than money. ${ }^{239}$

Another segment in which criminal contingent fees could suc-

238 See Wolfram, supra note 177 , at 538.

239 Sample clauses for the retainer agreement are set forth below:

MODEL CONTINGENT FEE CLAUSES

The compensation of Attorney shall be as follows:

In the event that all charges against client that attorney is hereby retained to represent client on are terminated in the (superior/inferior) court in one or more of the following manners, including any combination thereof: acquittal, dismissal with prejudice, or dismissal without prejudice and the charge(s) not refiled within six months after dismissal, then attorney shall be paid $\$ \mathrm{X}$.

In the event that attorney has not earned the fee provided for in the first paragraph, but in the further event client is not convicted of a felony (or retains driver's license, professional license, is not sentenced to term greater than $\mathbf{X}$ years, is not sentenced to incarceration, etc.) attorney shall be paid $\$ Y$.

If the contingent results described above are not obtained by attorney under this retainer agreement, but come about as the result of appellate review by any court of this State or the United States Supreme Court, then attorney shall be paid $\$ Z$, even if attorney shall not have provided services in the prosecution of the appeal. The obligation in this paragraph does not arise because of results obtained through post conviction proceedings such as petition for writ of habeas corpus or motion to vacate judgment of conviction.

[provision securing payment as by, e.g., mortgage or other security interest 
cessfully operate is in the twilight zone of indigency. Assessment of a defendant's indigency in determining eligibility for court-appointed counsel involves nebulous standards. ${ }^{240}$ Criminal defendants and their families have an incentive to conceal financial wherewithal from the court in an effort to get free counsel. Yet some of these people might be willing to risk their assets against freedom in a contingent fee arrangement in order to obtain counsel of choice. If this inducement to gamble seems exploitative, it should be borne in mind that such deceptive clients are not actually eligible for free legal assistance but are only making themselves appear to be. Real and perceived abuse of the assigned counsel system in the eligibility determination has been a special irritant to the private defense bar. Contingent fees might free up clients for the private market who do not belong on the legal aid dole.

It is also reasonable to assume that some of the financial and industrial wizards whose indictments have recently attracted much media coverage would be willing to bet with their lawyer on acquittal for a larger fee than the normal charge. Considering the collossal fines these defendants face, the gamble could make a lot of sense to them and the attorney. One can imagine that such clients might be willing to enter very sizable contingency fee arrangements. These wealthy, white-collar defendants might even perceive the lawyer willing to take such a gamble as a superior and more confident champion than the lawyer who is not. Wealthy defendants probably relish paying huge fees in a losing case even less than the middle class does.

One reason to repeal the ban on contingent fees is to see whether it is now depriving substantial numbers of clients of desired private counsel. It is not fairly predictable whether a substantial number of lawyers would move into the new market niche created by legitimizing contingent fees. Even if some attorneys express disdain toward contingent fees, that does not mean that all criminal attorneys will shun such arrangements.

made conditional upon result in case, conditional assignment of bail funds or other assets, escrow fund, etc.]

In addition to the above contingent obligations, client agrees to pay attorney, regardless of the result obtained in the case, [a nonrefundable retainer, hourly fee, stairstep arrangement, etc.].

Other items relating to compensation, including responsibility for expenses and the scope of the attorney's representation, must be in the retainer agreement. See, How to SET FEes, supra note 112, for forms.

240 Sheldon Krantz, Charles Smith, David Rossman, Paul Froyd \& Janis Hoffman, Right to Counsel in Criminal Cases: The Mandate of Argersinger v. Hamlin, 30914 (1976). 


\section{Congress and the Supreme Court Legalize Contingent Fees}

In 1989, the Supreme Court delivered a body blow to the private defense bar by holding that attorneys' fees are subject to restraint and forfeiture. ${ }^{241}$ The Court explicitly accepted a contingent fee arrangement when it rejected the argument that forfeiture possibilities would overly burden the right to counsel of one's choice. The majority, in Caplin E Drysdale, Chartered v. United States, 242 stated that the burden is limited: "Defendants ... may be able to find lawyers willing to represent them, hoping that their fees will be paid in the event of acquittal . ..."243 In the face of the Court's pronouncements implying the legitimacy of criminal contingent fees, state ethics codes and contracts caselaw seem puny indeed.

\section{A. CONTINGENCY IMPOSED BY POSSIBILITY OF FORFEITURE}

The background of the Court's decision in Caplin छ Drysdale was the federal Comprehensive Forfeiture Act of 1984,244 which amended both the Racketeering Influenced and Corrupt Organizations Act (RICO) statute ${ }^{245}$ and the Continuing Criminal Enterprise provision of the Comprehensive Drug Abuse Prevention and Control Act of 1970. ${ }^{246}$ The amendment provides for forfeiture to the Government of a guilty defendant's assets derived from or in other ways related to the crime; this is accomplished through an investiture of title to the assets in the government, the investiture relating back to the time of the crime. ${ }^{247}$ Courts are authorized to restrain transfer of potentially forfeitable assets prior to trial. ${ }^{248}$ If the defendant is convicted, the jury then determines whether to forfeit tainted assets, regardless of whether they have already been restrained or not. ${ }^{249}$

In United States v. Monsanto ${ }^{250}$ and in Caplin $\mathcal{E}^{\circ}$ Drysdale, Chartered

241 Caplin \& Drysdale, Chtd. v. United States, 491 U.S. 617, 635 (1989). See also, AssetForfeiture Ruling Outrages Bar, Legal Times, June 26, 1989, at 2; Drug Lawyers Leave Field, Fearing Fees Will be Seized, WAll St. J., Sept. 14, 1989, \& 2 at p.1.

242491 U.S. 617.

243 Id. at 625.

244 Comprehensive Forfeiture Act of 1984, Pub. L. 98-473, sec. 301, 98 Stat. 2040 (1984) (as amended and codified in relevant part at 21 U.S.C. sec. 853 et. seq. (1988)).

245 Racketeering Influenced and Corrupt Organizations Act, 18 U.S.C. secs. 1961-68 (1988).

246 Continuing Criminal Enterprise Act, 21 U.S.C. sec. 848 (1988).

24721 U.S.C. $\$ 853(c)$.

248 Id.

249 United States v. Jenkins, 904 F.2d 549, 559 (10th Cir.), cert. denied, 111 S.Ct. 395 (1990).

250491 U.S. 600,602 (1989). 
v. United States, ${ }^{251}$ the Supreme Court held that the statute applied to attorneys' fees paid or to be paid for the defense of forfeiture cases, so that the fees can be restrained and forfeited, and that as so applied to attorney's fees the statute was constitutional. The defense in Caplin E Drysdale had argued before the Supreme Court that the possibility of attorney forfeiture would create conflicts of interest similar to those raised by criminal contingent fees. ${ }^{252}$ The attorney would be allowed to collect his or her fee only if he or she defeated the forfeiture by outright acquittal or by showing the fee was from untainted funds. The defense argued that several conflicts would potentially result. First, the attorney would fail to diligently investigate the case in order to remain ignorant of the source of the fee funds so that the attorney would hold the status of a bona fide purchaser not subject to disgorgement of forfeited assets. ${ }^{253}$ Second, the attorney would engage in plea bargaining against the client's interest to keep the fee (i.e., through structuring the bargain to protect the fee in derogation of the client's principal interests). ${ }^{254}$ Third, the attorney would risk going to trial and turning down a plea bargain in order to gain acquittal and hence escape forfeiture. ${ }^{255}$ The ABA argued in an amicus brief that, if collection of the fee is contingent on acquittal, serious ethical concerns are raised, and it cited its own prohibition on criminal contingent fees. ${ }^{256}$ The bulk of the ABA's ethics arguments were devoted to other considerations. ${ }^{257}$

Before the Supreme Court, the Government in Caplin $\mathcal{E}$ Drysdale

251491 U.S. 617,619 (1989).

252 Id. at 632-33 n.10 (quoting Brief for Petitioner at 36-37, Caplan \& Drysdale, Chtd. v. United States, 491 U.S. 617 (1989) (No. 87-1729)).

$253 \mathrm{Id}$. The attorney could release his fee from forfeited funds by establishing that he is a bona fide purchaser for value of the funds who was reasonably without cause to believe the funds were subject to forfeiture-a difficult burden for the very lawyer who knows the client faces forfeiture. 18 U.S.C. $\$ 1963(\mathrm{l})(6)(B)$ (1988); 21 U.S.C. $\S 853(\mathrm{n})(6)(\mathrm{B})(1988)$.

254 Caplan, 491 U.S. at 632-33.

255 Id.

256 Id. at 632-33 n.10 (quoting Brief for the ABA as Amicus Curiae at 17, Caplin \& Drysdale, Chartered v. United States, 491 U.S. 617 (1989) (No. 87-1729)).

257 ABA Amicus Brief at 17-22, Caplin (No. 87-1729). Similar ethics arguments had been rejected by a Court of Appeals judge in the case on ad hominem grounds; he saw a constitutional attack on a statute which compels a contingency fee as an example of the legal profession being "money grubbing." The judge fulminated that when the shoe is on the other foot and contingent fees are attractive to the personal injury lawyer, the lawyer will not take an hourly fee but will insist on a contingent fee to earn more money. In re Forfeiture Hearing as to Caplin \& Drysdale, Chtd., 837 F.2d 637, 650 (4th Cir. 1988) (en banc) (Murnaghan, J. concurring), aff'd, 491 U.S. 617 (1989). A dissenting judge answered this diatribe by arguing that the civil analogy is so irrelevant "one wonders if the real thought is not that there are also bad lawyers to be taken into account in 
sought to minimize ethical concerns. It argued that the ethics problem was hypothetical and should not be decided; that the conflicts argument regarding a possible plea bargain to preserve the fee had been rejected; ${ }^{258}$ that there was no actual contingent fee in the case; that there was no contingent fee issue peculiar to the forfeiture statute because in many cases if defendant is convicted he cannot work to pay off the fee; that the prohibition on contingent fees rests in large part on the public interest in avoiding temptation to corruption and not in protecting a defendant's interests; that contingent fee problems do not raise constitutional issues; and, that Congress could rationally conclude that a fee resembling a contingent fee is better for the integrity of the criminal justice system than allowing drug profits to pay fees. ${ }^{259}$

Just as the Government's arguments were briefed mostly in footnote, ${ }^{260}$ the Supreme Court dealt with the ethical concerns in a footnote. The Court said that a mere reading of the indictment would remove any chance that the attorney would not know the source of his fee, so not being ignorant, he would have no incentive not to investigate the case fully. ${ }^{261}$ And plea bargaining against the client's interest to preserve the fee would "surely constitute ineffective assistance of counsel" and the defendant would have a remedy. ${ }^{262}$ (This was surprising optimism from a Court which has made it extremely difficult to vacate convictions on the ground of ineffective assistance of counsel. ${ }^{263}$ )

Four dissenting justices in Caplin $\mathcal{E}$ Drysdale read the Court's disposition of the cases as creating a contingent fee situation that

assessing the governmental interests at stake." 837 F.2d at 652 n.3 (Phillips, J. dissenting).

258 Proceedings in Vindication of Civil Rights; Attorney's Fees, 42 U.S.C. \$ 1988 (1988), provides for awards of attorneys fees to a prevailing plaintiff. In Evans v. Jeff D., 475 U.S. 717 (1986), the Supreme Court had ruled that the statute did not prohibit judicial approval of class action settlements that were conditional on plaintiff waiving his claim for attorneys fees. The Court reasoned there was no ethical duty to seek such a fee, and in this case plaintiff's counsel had recommended the settlement. Id. at 728. The statute was interpreted to permit this kind of settlement despite the argument that offers of settlements conditioned upon waiver of attorneys fees would exploit opposing counsel's ethical obligations to his client. Id. The Court noted the attorney's general ethical duty not to be swayed by his own interests. Id. at 728 n.14.

259 Brief for the Respondent at 40-41, Caplan \& Drysdale, Chtd. v. United States, 491 U.S. 617 (1989) (No. 87-1729).

260 Id. at $41 \mathrm{n} .21$.

261 Caplin, 491 U.S. at 632 n.10.

262 Id. See supra notes 163-64 and accompanying text. The Court said it had rejected a "similar" claim in Evans v. Jeff D., 475 U.S. 717, 727-28 (1986); See supra note 258.

263 See, e.g., United States v. Cronic, 466 U.S. 648 (1984); Strickland v. Washington, 466 U.S. 668 (1984). 
places the attorney in an ethical violation unless he has first received payment from a supposedly untainted source. ${ }^{264}$ Even if the defendant finds a lawyer "so foolish, ignorant, beholden or idealistic as to take the business," the attorney's integrity would be questionable because of his willingness to violate ethical norms. ${ }^{265}$ The dissent seemed to believe that the attorney could remain ignorant of the source of assets used to pay his fee, and thus avoid the contingent fee prohibition, but that this, however, would lead to inadequate investigation of the case. ${ }^{266}$

\section{B. ETHICS AND THE CONSTITUTIONAL RIGHT TO COUNSEL}

In Caplin $\mathcal{E}$ Drysdale, the Court found the relationship between the alleged allowance of contingent fees and the constitutional issue of the Sixth Amendment right to counsel weak: "The fact that a federal statutory scheme authorizing contingent fees-again, if that is what Congress has created in $\$ 853$ (a premise we doubt)-is at odds with model disciplinary rules or state disciplinary codes hardly renders the federal statute invalid." 267 Here the Court was correct: Congress can supersede state constitutions, and it can certainly supersede mere ABA model codes incorporated into state ethics regulations, without running afoul of federal constitutional rights. ${ }^{268}$ Ethical considerations might bear on the question of Congress's intent in requiring forfeiture of attorney fees, but there was too little legislative history for the Court to dwell upon that possibility. ${ }^{269}$

Having interpreted the forfeiture statute as reaching attorney's fees, the Court upheld the statute against attack under the Sixth Amendments provision establishing the right to counsel. ${ }^{270}$ The Court did not discuss its precedents on the relationship of ethics to the constitutional right to counsel. As with legislative history, ethics rules are used by the Court when they support the Court's decision and brushed aside when they do not. ${ }^{271}$

\footnotetext{
264491 U.S. at 649 (Blackmun, J. dissenting).

265 Id. (quoting United States v. Badalamenti, 614 F.Supp. 194, 196 (S.D.N.Y. 1985)).

266 Caplin, 491 U.S. at 650.

267 Id. at 633 n. 10.

268 Id.

269 United States v. Monsanto, 491 U.S. 600, 608-10 \& n.8 (1989).

270 Caplin, 491 U.S. at 632 . The Court interpreted the statute in United States v. Monsanto, 491 U.S. 600, 611-14 (1989).

271 See, e.g., McCoy v. Court of Appeals of Wisc., 486 U.S. 429, 440 (1988) (rule requiring withdrawing assigned appellate counsel to discuss why the issues lack merit carries out the ethical obligation of candor); Wheat v. United States, 486 U.S. 153, 160 (1988) (no constitutional right to have court approve client's waiver of multiple-representation conflict; ethics rules impose limits on multiple representation. Id. at 162.); Burger v. Kemp, 483 U.S. 776, 777-78 (1987) (even if multiple representation gives rise
} 
Clearly the contingent fee ban did not present the Court with a ground for decision, the validity of criminal contingent fee agreements not being the issue. Counsel was trying to use the contingency ethics tail to "wag" the Sixth Amendment right to counsel "dog," an argument that had had some impact on lower courts willing to view the statute or the Constitution favorably to the defense. ${ }^{272}$ It would have lent unprecedented and surprising force to

to conflict of interest, no ineffective assistance of counsel based on analysis of lawyer's conduct.); Nix v. Whiteside, 475 U.S. 157, 174-75 (1986) (right to counsel does not include right to cause the lawyer to violate ethics by allowing his client to commit perjury; four concurring justices disagree with the broad sweep of the majority opinion's implied "adoption of a set of standards of professional responsibility for attorneys in state criminal proceedings" by giving weight to the ABA amicus suggestion that the Model RULes should govern the attorney's responsibilities. Id. at 189.); United States v. Young, 470 U.S. 1 (1985) (defendant's summation invited prosecutor's response; defendant was prohibited by ethics from interjecting his personal beliefs); Jones v. Barnes, 463 U.S. 745, 753 n.6 (1983) (no constitutional right to have assigned appellate counsel raise non-frivolous issue on appeal; Court notes that even if ABA STANDARDS appear to allow client to decide what non-frivolous issues are to be raised, "the fact the ABA may have chosen to recognize a given practice as desirable or appropriate does not mean that the practice is required by the Constitution." Id.); Polk County v. Dodson, 454 U.S. 312, 318-19 (1981) (ethics means that a public defender is a lawyer serving his client; he is not acting under color of law for civil rights purposes.); Wood v. Georgia, 450 U.S. 261, $269 \mathrm{n} .15$ (1981) (lawyer paid by third party; possible conflict so court should have inquired); Cuyler v. Sullivan, 446 U.S. 335, 346-47 (1980) (trial court need not inquire regarding conflict of interest from multiple representation unless an objection is made; counsel has an ethical duty to advise the court of conflict.); Ferri v. Ackerman, 444 U.S. 193, 200-01 n.17 (1979) (ethics means that assigned counsel is not immune from a state law malpractice suit); Maness v. Meyers, 419 U.S. 449, 466-67 n.16 (1975) (lawyer must not favor his own interests, so no contempt for his advice to invoke privilege); Escobedo v. Illinois, 378 U.S. 478, 487 n.7 (1964) (prohibiting interrogated suspect from communicating with his retained attorney violated his consitutional rights; canon prohibiting communicating with party represented by attorney cited). Cf. United States v. Henry, 447 U.S. 264, 275 n.14 (1980) (government communication with defendant is jail cell via informant violates right to counsel; Court cites but eschews reliance on ethical prohibition of communicating with party known to be represented by counsel); Glasser $\mathbf{v}$. United States, 315 U.S. 60 (1942) (seminal case on right to counsel and multiple-representation conflict; ethics not averted to).

272 United States v. Badalamenti, 614 F. Supp. 194, 196 (S.D.N.Y. 1985); United States v. Ianniello, 644 F.Supp. 452, 457 (S.D.N.Y. 1985) (forfeiture of attorneys fees violates 6th Amendment; inter alia, defense counsel might be considered as having accepted a forbidden contingent fee, citing MODEL CoDE, supra note 4, at DR 2-106(c) n.3 (on corrupting justice); attorney might want to plea bargain to avoid forfeiture instead of acting in client's best interest, or go to trial to get a favorable verdict, citing MODEL CoDE, supra note 4, at DR 5-103(A) (on advising to client's benefit)). See United States v. Harvey, 814 F.2d 905, 921 (4th Cir. 1986) (counsel might not investigate fully in order to remain ignorant of source of assets to pay fee, or plea bargain to retain fee), rev'd sub nom., In re Forfeiture Hearing, 837 F.2d 637 (4th Cir. 1988) (en banc), aff'd sub nom., Caplin \& Drysdale, Chtd. v. United States, 491 U.S. 617 (1989); United States v. Bassett, 632 F.Supp. 1308, 1316 n.5 (D. Md. 1986) (counsel argues that if he agrees to represent defendant without an order exempting his fee from forfeiture, he is violating contingent fee ban; motion was granted). 
ethics rules to hold that the rules invalidated a statute, or even that they compelled an interpretation of the statute against its plain meaning. ${ }^{273}$

\section{FORMAL VS. PRACTICAL CONTINGENCY AND THE FUTURE OF CONTINGENT FEES}

In its contingent fee footnote, the Court accepted the Government's position that there was no contingent fee agreement in the case:

There is no indication here that petitioner, or any other firm, has actually sought to charge a defendant on a contingent basis; rather the claim is that a law firm's prospect of collecting its fee may turn on the outcome at trial. This, however, may often be the case in criminal defense work. ${ }^{274}$

The implication was that, unless the agreement explicitly made the client liable only in the event of acquittal, it did not create a contingent fee even though receiving the money was for all practical purposes contingent on the outcome of the case.

The Court's fixation on the terms of the agreement is oddly wooden. If the lawyer and client believe that there will be no payment absent acquittal, it is hard to see why the absence of contractual liability conditioned on acquittal is material. For instance, suppose that in a personal injury case the agreement provided that the client would pay $\$ 25,000$ as a fee, but both parties to the agreement knew that the client did not have the funds, and that the fee would be paid only in case of a substantial recovery. In terms of the policy issues revolving around contingent fees this does not seem any less of a contingent fee contract than an agreement explicitly providing that the fee will be paid only in the event of the recovery. If the attorney and client do not care as much about the contract as they do about the practical reality, then the Court should not govern their conduct on any basis other than that reality. The Court may have been correct in the trivial sense that the parties to the case before it did not know that the statute would be held to encompass the fee and therefore there was no expectation of contingency, but certainly lawyers and clients would expect contigency from the date of the 1989 decision. ${ }^{275}$

273 See supra note 271.

274 Caplin, 461 U.S. at 633 n. 10.

275 There are apparently no reported cases that have passed upon agreements that did make the client's liability for the fee only practically contingent, as distinguished from practically and contractually contingent. But Cf. Chicago Bar Comm. on Ethics and Professional Responsibility Op. 84-9 (1985), reported in National Reporter on Legal ETHICS AND RESPONSBILITY IL:Opinions: 25 (1985) (fee for criminal case contingent on 


\section{THE PRESENT AND FUTURE OF CONTINGENT FEES}

After Caplin $\mathcal{E}$ Drysdale, functional criminal contingent fees, at least in federal forfeiture cases, are now probably lawful. A contract that explicitly creates a contingent fee may not be any more valid after the Court's decision than before, but arrangements under which the parties understand that the lawyer will not be paid unless he or she obtains a release of the client's funds might be enforced by state courts out of respect for the Supreme Court's decision. Alternatively, state courts might enforce such a rule because there is now a class of cases where clients would have almost no other chance of retaining private counsel, and the policy of making legal representation available might be seen as paramount. The agreement to pay may be unconditional, but the contingency is built in by the surrounding circumstances, i.e., the reasonable possibility that the Government will seek forfeiture of the assets that must be used to pay the attorney in the case. To insure payment, the assets in jeopardy might be assigned to the lawyer or otherwise secured for release in the event of acquittal.

The Supreme Court's ruling might give impetus to state courts to overrule their case law making contingent fee contracts unenforceable even in nonforfeiture cases and even when formally contingent. There is also the possibility that judges applying state contract law will not find the Supreme Court's holding in the forfeiture cases binding or persuasive, because the cases applied federal law that did not regulate contingent fee agreements, and because state judges do not think the Supreme Court was really concerned with contingent fee policies so much as it was trying to dispose of a pesky issue. Finally, state court recalcitrance in enforcing contingent fee agreements could cause federal courts to supersede state contract law with a federal common law in aid of the federal criminal justice system upholding contingent fee agreements made in forfeiture cases.

Given the precise black-letter prohibition in the codes, explicit contingent fees even in forfeiture cases remain unarguably unethical, unless the Supreme Court's decision is interpreted as federal pre-emption of state ethics rules.

Up to this point, there has been no conflict between the ethical contingent fee prohibition and an attorney's "obligation" to make private defense services available to forfeiture defendants, because

winning civil rights suit arising out of the arrest is ethical; no contingency in criminal case; opinion overlooks possible conflict: attorney must go for acquittal in criminal case because lesser offense conviction would legally and practically kill the civil rights case.). 
there is no such obligation to them or to any other accused, despite hortatory language. ${ }^{276}$ Removal of the ethics ban on criminal contingent fees will give that hortatory language some teeth, or at least a tooth.

\section{Conclusion}

The prohibition on criminal contingent fees springs from irrelevant conceptual thinking, unverified concerns regarding conflict of interest, and prejudice against criminal attorneys and what they do. These concerns do not provide sufficient reason to bar lawyers and clients from entering into beneficial agreements. Repeal of the ban on criminal contingent fees would be of particular benefit to the middle class, who will be eager to pay for results instead of services. Data could then be obtained on whether there actually are problems such as conflict of interest. After all, repeal does not preclude regulation or supervision, and certainly does not preclude reinstatement of the ban in the event empirical evidence points out insurmountable problems. Either way, the Supreme Court's decision creating de facto contingent fee cases presents an ideal opportunity to repeal the ban and see what happens.

276 Such as "[a] basic tenet of the professional responsibility of lawyers is that every person in our society should have ready access to the independent professional services of a lawyer of integrity and competence." Model Code, supra note 4, at EC 1-1. 